\title{
Title: Potential Role of (-)-epigallocatechin-3-gallate (EGCG) in the Secondary Prevention of Alzheimer Disease
}

\author{
Laura Xicota $^{\mathrm{a}, \mathrm{b}, \mathrm{c}}$, Jose Rodríguez-Moratón ${ }^{\mathrm{ab}, \mathrm{d}}$, Mara Dierssen ${ }^{\mathrm{b}, \mathrm{c}, \mathrm{e}}$ and Rafael de la Torre ${ }^{\text {a,b,d }}$ \\ ${ }^{a}$ Integrative Pharmacology and Systems Neuroscience Research Group, Neurosciences Research Program, IMIM- \\ Institut de Hospital del Mar d'Investigacions Mèdiques, Barcelona, Spain; ${ }^{b}$ Universitat Pompeu Fabra, Barcelona, \\ Spain; ${ }^{C}$ Cellular \& Systems Neurobiology, Systems Biology Program, Centre for Genomic Regulation, Barcelona, \\ Spain; ${ }^{d}$ CIBER de Fisiopatología de la Obesidad y Nutrición (CIBEROBN, CB06/03/028), Santiago de Compostela, \\ Spain; ${ }^{e}$ Centro de Investigación Biomédica en Red de Enfermedades Raras (CIBERER), Spain
}

\begin{abstract}
Medical advances in the last decades have increased the average life expectancy, but also the incidence and prevalence of age-associated neurodegenerative diseases. Alzheimer disease (AD) is one of the most common neurodegenerative diseases and the most prevalent type of dementia. A plethora of different mechanisms contribute to $\mathrm{AD}$, among which oxidative stress plays a key role in its development and progression. So far, there are no pharmacological treatments available and the current medications are mainly symptomatic. In the last years, dietary polyphenols have gained research attention due to their interesting biological activities, and more specifically their antioxidant properties. (-)-epigallocatechin-3-gallate (EGCG) is a natural flavanol that has been extensively studied regarding its potential effects in $\mathrm{AD}$. In this review we present the current in vitro and in vivo experimentation regarding the use of EGCG in AD. We also review the complex mechanisms of action of EGCG, not only limited to its antioxidant activity, which may explain its beneficial health effects.
\end{abstract}

Keywords: Alzheimer disease; (-) epigallocatechin-3-gallate; green tea; neurodegenerative diseases; neuroprotection; oxidative stress

\section{NEURODEGENERATIVE DISEASES}

Neurodegenerative diseases are a wide and heterogeneous group of disorders whose common characteristic is a selective functional failure of the brain and/or spinal cord neurons, which leads to a progressive nervous system dysfunction. In spite of the multifactorial etiology and pathogenesis of this broad group of diseases where aging is a major risk factor, the production of reactive oxygen species (ROS) and mutations in mitochondrial DNA (mtDNA) have been postulated as common contributing factors for the initiation and development of these diseases [1]. However, in contrast to the mitochondrial free radical theory of aging, evidence from an increasing number of experimental studies has suggested that mtDNA mutations may be generated by replication errors rather than by accumulated oxidative damage [2].

*Address correspondence to Rafael de la Torre at the Human Pharmacology and Clinical Neurosciences Research Group, Neurosciences Research Program, IMIM (Hospital del Mar Medical Research Institute), Doctor Aiguader, 88, 08003, Barcelona, Spain. Tel/Fax: +34 933160 484, +34 933 160 467; E-mail: rtorre@imim.es

Since Harman published his theory associating for the first time free radicals with aging in 1956 [3], the knowledge in this field has experienced much progress and yet, is still controversial [4], especially due to the reduced effectiveness of the clinical treatments aiming at minimizing the effects and consequences of oxidative stress [5]. Redox reactions between specific proteins (such as amyloid- $\beta(\mathrm{A} \beta)$ and $\alpha$ synuclein) and transition metals (specially $\mathrm{Zn}, \mathrm{Cu}$, and $\mathrm{Fe}$ ) originate the majority of brain ROS, and it has been suggested that the brain accumulation of $A \beta$ proteins may be a protective response to oxidative stress [6]. This is in part based on the observation that regions of the brain rich in $A \beta$ proteins also have increased levels of protein oxidation [7]. ROS are highly reactive, target lipids, proteins, and DNA, and are able to disrupt intracellular calcium homeostasis, leading to excitotoxicity. Abnormally high levels of calcium activate a wide number of pathways including the glutamate receptors whose excitotoxic response leads to cell death [8].

Redox reactions occur naturally in our cells and ROS are constantly produced by the mitochondria as by-products of the electron transport chain reactions. To prevent cell damage, the antioxidant system, a complex defense system, faces the toxic ROS accumulation, attenuating its net production. This complex endogenous antioxidant defense system is constituted by enzymatic components (such as superoxide dismutases, catalase or glutathione peroxidase) and non-enzymatic components (such as glutathione or $\alpha$ tocopherol), and minimizes the excessive formation of reactive species (Table 1). Unfortunately, this system is not always entirely effective and therefore oxidative damage can injure several tissues (the brain being especially sensitive to 
it), resulting in chronic diseases [9] and neurodegeneration [8]. ROS are in fact a threat only upon imbalance between their production and the antioxidant system.

Table 1: Examples of enzymatic and non-enzymatic components of the antioxidant system, and some of the most common ROS. An overproduction

\begin{tabular}{|c|c|c|c|c|}
\hline \multicolumn{3}{|c|}{ The antioxidant system } & \multicolumn{2}{|c|}{ Reactive oxygen species (ROS) } \\
\hline Non-enzymatic & Enzymatic con & nents & Radicals & Non-radicals \\
\hline $\begin{array}{l}\alpha \text {-Tocopherol } \\
\text { (vitamin E) }\end{array}$ & $\begin{array}{l}\text { Superoxide } \\
\text { dismutases } \\
\text { (SOD) }\end{array}$ & Peroxiredoxins & $\begin{array}{l}\mathrm{O}_{2}^{-} \\
\text {(Superoxide) }\end{array}$ & $\mathrm{O}_{3}$ (ozone) \\
\hline Coenzyme $\mathrm{Q}_{10}$ & Catalase & Glutaredoxin & $\begin{array}{l}\mathrm{OH}^{*} \\
\text { (Hydroxyl) }\end{array}$ & $\begin{array}{l}\mathrm{H}_{2} \mathrm{O}_{2} \\
\text { (hydrogen } \\
\text { peroxide) }\end{array}$ \\
\hline $\begin{array}{l}\text { Glutathione } \\
\text { (GSH) }\end{array}$ & $\begin{array}{l}\text { Glutathione } \\
\text { peroxidase }\end{array}$ & Thioredoxin & $\begin{array}{l}\mathrm{NO}^{\circ} \\
\text { (Nitric } \\
\text { oxide) }\end{array}$ & $\begin{array}{l}{ }^{1} \mathrm{O}_{2} \\
\text { (singlet } \\
\text { oxygen) }\end{array}$ \\
\hline $\begin{array}{l}\text { Ascorbic acid } \\
\text { (vitamin C) }\end{array}$ & $\begin{array}{l}\text { Gluthatione } \\
\text { reductase }\end{array}$ & $\begin{array}{l}\text { Thioredoxin } \\
\text { reductase }\end{array}$ & $\begin{array}{l}\text { ROO }^{\circ} \\
\text { (Peroxyl) }\end{array}$ & $\begin{array}{l}\text { ONOO}^{-} \\
\text {(Peroxynitrite) }\end{array}$ \\
\hline Melatonin & $\begin{array}{l}\text { Phospholipid } \\
\text { hydroperoxide } \\
\text { glutathione } \\
\text { peroxidase }\end{array}$ & Cytochrome $c$ & $\begin{array}{l}\mathrm{RO}^{\bullet} \\
\text { (Alcoxyl) }\end{array}$ & $\begin{array}{l}\mathrm{O}_{2} \mathrm{NOO}^{-} \\
\text {(Peroxynitrate) }\end{array}$ \\
\hline
\end{tabular}

of ROS or a dysfunction of the antioxidant system causes an imbalance that leads to oxidative stress.

Although in some cases radicals are considered a unique entity, their chemical reactivity and, consequently, their toxicity vary significantly. The highly reactive hydroxyl radical is probably always harmful [10], whereas nitric oxide plays a wide variety of roles in vivo, for example, as a messenger molecule or controlling the systemic blood pressure and respiration [11]. Indeed, several ROS are second messengers that regulate normal cell functions and control cell signaling pathways [12]. Strikingly, one of the functions of ROS is the modulation of long-term potentiation (LTP) in the hippocampus. Both superoxide and hydrogen peroxide are involved in LTP. LTP studies in the rodent hippocampus have revealed that the scavenging of superoxide blocks high-frequency stimulation LTP (HFSLTP) [13], suggesting that superoxide is required for HFSLTP. Conversely, overproduction of $\mathrm{H}_{2} \mathrm{O}_{2}$ as a by-product of superoxide dismutase (SOD) activity was shown to inhibit LTP [14]. This action, however, seems to depend on different factors including the kind of ROS, its concentration, and the age of the organism [15].

\section{ALZHEIMER DISEASE}

In developed countries, the increase in life expectancy has increased the incidence and prevalence of diseases related to aging, such as neurodegenerative disorders [16, 17]. Of those, $\mathrm{AD}$ is the most common [18]. According to the World Alzheimer Report 2009, nearly 40 million people worldwide are living with dementia and this prevalence is estimated to increase up to 66 million people by 2030, and to 115 million by $2050[19,20]$. The progressive decline of cognitive ability is the main clinical symptom of $\mathrm{AD}$, already described in the original report of 1907 along with the neuropathological features [21, 22], and that results in the loss of daily functioning. The etiology of $\mathrm{AD}$ remains unclear, but the underlying neurodegenerative processes are thought to start between 20 and 30 years before the observation of the first clinical symptoms [18]. However, genetic studies related to $\mathrm{AD}$ have connected autosomal dominant mutations in the $A P P$, presenilin- 1 and -2 genes with early onset familial $\mathrm{AD}$ (FAD, rare forms that appear before 60 years of age). The inheritance of the $\varepsilon 4$ allele of apolipoprotein E (ApoE4) is a well-established genetic risk factor for late onset sporadic AD [23, 24] although its mechanism of action is not well established [25].

\subsection{Pathophysiological findings in Alzheimer Disease}

The clinical symptoms of $\mathrm{AD}$ (loss of cognitive abilities and impairment in executive function) are the manifestation of an underlying neurodegenerative process affecting cortical and subcortical brain regions. The causal mechanisms of this neurodegenerative process are not understood, but neuropathological hallmarks of $\mathrm{AD}$ include the accumulation of extracellular neuritic (also named senile, or amyloid) plaques of $\mathrm{A} \beta$ peptides, and intracellular neurofibrillary tangles (NFT), which major component is hyperphosphorylated tau protein [1]. Both senile plaques and NFT are composed of misfolded proteins. Massive neuronal cell loss, synapse loss, and cerebral atrophy are also observed [16].

$\mathrm{AD}$ is associated with chronic neuroinflammation. This inflammatory process is understood as the activation of microglia and astrocytes, leading to increased concentrations of cytokines and chemokines that can cause cell loss, neurodegenerative changes, and the disruption of the bloodbrain barrier. $\mathrm{AD}$ brains are characterized by an increased gliosis, especially with activated astrocytes and microglia close to the amyloid plaques. The chronic neuroinflammation ends up inducing necrosis by several mechanisms, including oxidative stress [26], that in turn induces neuroinflammation, generating, thus, a positive feedback mechanism [27].

Finally, the neuronal loss affects specific cell populations. For example, the degeneration of the basal forebrain cholinergic nuclei led to the hypotheses that $\mathrm{AD}$ was caused because of a cholinergic dysfunction [28] $\mathrm{AD}$ brains show decreased ChAT (Choline Acetyltransferase) activity, leading to decreased concentrations of acetylcholine $[29,30]$, and reflecting the cholinergic cell loss. The only treatment currently used in clinics for $\mathrm{AD}$ is based in this observation [28]. Alternatively, $\mathrm{AD}$ is considered a misfolding protein disease where tau protein or $A \beta$ initiate 
the disease. The amyloid hypothesis is at present the most likely cause of the damage that underpins $\mathrm{AD}$.

\subsubsection{Alzheimer disease as a misfolding protein disease: the amyloid hypothesis}

The amyloid hypothesis postulates that in AD abnormal processing of amyloid precursor protein (APP) in the brain leads to an increased production of a short fragment of APP known as $A \beta$, and the formation of amyloid plaques. The major components of these plaques are $A \beta$ peptides, which are 38 to 42 amino acids in length. $A \beta$ peptides tend to aggregate and form neurotoxic oligomers that are now considered to cause the memory impairment present in $\mathrm{AD}$ [18]. There is growing evidence that soluble oligomeric clusters of $A \beta$ are important for the early synaptic failure seen in $A D$ pathogenesis [31]. However, even though $A \beta$ was initially thought to be causative of the disease, in fact there is poor correlation between dementia and the plaque burden [32].

$A \beta$ peptides are generated by the proteolytic cleavage of APP, a transmembrane protein with a single-membrane spanning domain [18]. APP and its metabolites have several proposed functions including various roles in early brain development, synaptogenesis, synaptic plasticity, adaptation to brain ischemia, control of cholesterol metabolism, modulation of acetylcholinesterase (AChE), as well as in the regulation of the epigenome towards the expression of $\mathrm{AD}$ genes [33]. Two different pathways for processing APP have been described. The difference between them lies in the proteases involved in APP cleavage; these enzymes are the key elements that determine $\mathrm{A} \beta$ peptides formation (Figure 1). In physiological conditions up to $90 \%$ of APP metabolism is through the non-amyloidogenic pathway, which comprises both $\alpha$ and $\gamma$-secretase processing. The first step of this pathway consists in the cleavage of APP at 83 amino acids from the $C$-terminus through $\alpha$-secretase enzymatic activity [34] (mainly ADAM metallopeptidase domain 10 -ADAM10 [35]), generating an extracellular $N$ terminal soluble fragment (called $\operatorname{sAPP} \alpha$ ) and a membraneassociated $C$-terminal fragment of 83 residues (known as $\alpha$ CTF or C83). This cleavage takes place within the $A \beta$ region, thus preventing the formation of the toxic peptide, and leading to a potential neuroprotective effect [34]. sAPP $\alpha$ is also known to promote neurogenesis [36]. Afterwards, $\alpha$ CTF is processed by $\gamma$-secretase and produces a small peptide called p3 [37]. This enzyme is a protease complex composed by at least four subunits, the proteolytic site being contained in the presenilin protein [32]. Additionally, there is a minor non-amyloidogenic route through ß-site APPcleaving enzyme-2 (BACE-2) activity $[38,39]$ that can lower $A \beta$ levels via $\alpha$-secretase-like cleavage of APP within the Aß sequence [40], an activity that has been dubbed " $\theta$-secretase" [41, 42].

Alternatively, the amyloidogenic processing takes place by a sequential cleavage by $\beta$ - (also known as $\beta$ - site APP cleaving enzyme- BACE-1) and $\gamma$-secretases. In the first cleavage, the $\beta$-secretase carries out the proteolysis at 99 amino acids from $C$-terminus releasing an extracellular $N$ - terminal soluble fragment (sAPP $\beta$ ) and the complementary C-terminal 99 amino acid fragment is retained in the membrane ( $\beta$-CTF or C99). The subsequent cleavage of this fragment by the $\gamma$-secretase generates the toxic $A \beta$ peptide [43]. The $\gamma$-secretase cleavage (by either amyloidogenic or non-amyloidogenic pathway) also generates a cytosolic fragment known as APP intracellular domain (AICD) [37]. AICD has been proposed to be a transcriptional regulator of several proteins when forming a complex with Fe65 and Tip60. Among the genes that could be regulated by AICD there are several AD related proteins, including APP, BACE1, and NEP (neprilysin). Furthermore, AICD overexpression alters PTCH1 (Patched homolog 1) expression, thus, modifying the Shh (Sonic hedgehog) pathway, which is involved in adult neurogenesis [33]. The increased $A \beta$ production in the brain of $\mathrm{AD}$ patients is the cause of yet another characteristic of the disease, which is brain insulin resistance. The amyloid oligomers trigger the TNF- $\alpha / \mathrm{JNK}$ pathway promoting the phosphorylation of IRS-1 (Insulin receptor substrate 1) inactivating it and enhancing its internalization, leading to a decreased insulin sensitivity paralleling the one seen in Type 2 diabetes [44].

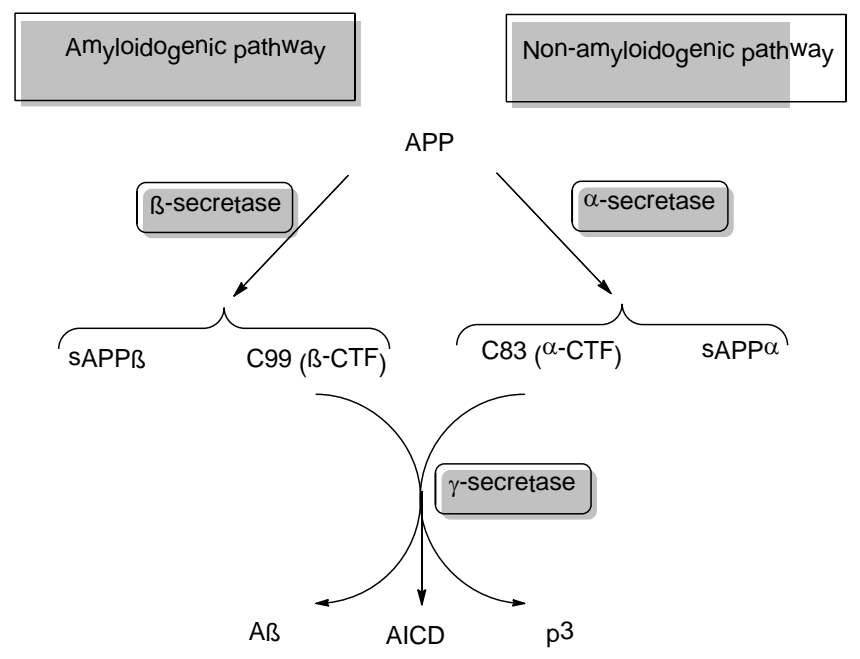

Figure 1: Representation of amyloid precursor protein (APP) processing. The amyloidogenic pathway takes place by a sequential cleavage by $\beta$ secretase (BACE- 1) and $\gamma$-secretase, which generates the toxic A $\beta$ peptide. Alternatively, the non-amyloidogenic pathway includes the $\alpha$-secretase proteolytic cleavage of APP within the A $\beta$ region, which prevents the A $\beta$ formation. Abbreviations: APP: Amyloid precursor protein; $s A P P \beta$ : $\beta$ secretase cleaved soluble amyloid precursor protein; sAPP $\alpha$ : $\alpha$-secretase cleaved soluble amyloid precursor protein; CTF: C-terminal fragment; AICD: Amyloid precursor protein intracellular domain.

Recent reappraisals of the amyloid cascade hypothesis have highlighted that $A \beta$-independent factors may also contribute to the disease process. Interestingly, patients with Down syndrome (DS), which present excess of $\mathrm{A} \beta$ peptides in their brain, have a high prevalence of $\mathrm{AD}$ and are prone to develop this disease at younger age than the normal population [45, 46]. The APP gene is located in chromosome 
21 (HSA21), and thus, in DS patients there is one extra copy of this gene, which is considered to be responsible for the excessive amount of $A \beta$ peptides in their brain [47, 48]. However, the APP gene is not the only gene present in HSA21 that has a role in the development of AD. DYRK1A, which encodes for the dual-specificity tyrosinephosphorylation-regulated kinase, is also overexpressed in DS, and an increased immunoreactivity against this kinase is observed in several AD brain regions [49]. The targets of this kinase include the AD related proteins APP, tau, and $\alpha$ synuclein [49-51]. Furthermore, DYRK1A phosphorylates PSEN-1 (presenilin 1) increasing its half-life and the $\gamma$ secretase activity [52], and $A \beta$ can increase DYRK1A mRNA levels, generating a positive feedback [53].

Tau is also a DYRK1A target, and tau phopshorylation by DYRK1A primes it for GSK-3 $\beta$ phosphorylation, leading to the hyperphosphorylated state [49]. Interestingly, DYRK1A protein has been found to be associated with NFT in sporadic $\mathrm{AD}$, possibly through tau phosphorylation. The aggregation of the hyperphosphorylated tau into paired helical filaments gives rise to the NFT that have been associated with cognitive decline in AD [54]. Tau is a protein involved in microtubule assembly and stabilization [18] that contributes to neuronal plasticity and consolidation of the neuronal network [54]. In the course of the disease, hyperphosphorylated tau polymerizes into filaments that constitute the NFT, which formation and accumulation is considered toxic. During the last decade, this assumption has been questioned [55] and the tangles have even been considered protective against the oxidative damage that precedes $\mathrm{AD}$ clinical manifestations [54]. Nonetheless, although neither $A \beta$ peptides nor NFT are exclusive to $A D$, when a high number of senile plaques or NFT are present, they are used for diagnosis and considered pathognomonic for the disease [56]. These combined observations raise the possibility that DYRK1A may be a critical contributor to tau dysfunction and tau pathology of $\mathrm{AD}$ and, moreover, that this kinase may be an important therapeutic target for pharmacological interventions seeking to modify the course of tau pathology in AD.

\subsubsection{Oxidative stress}

As stated above, neuronal cell loss in AD has been related, among other mechanisms, to oxidative stress and an excessive generation of free-radicals [57]. Oxidative damage takes place in the $\mathrm{AD}$ brain before the observation of the plaques and it has been identified as the earliest event in this disease [58]. The sensitivity of the brain to oxidative stress is caused mainly by its low levels of antioxidant enzymes and molecules, and its richness in polyunsaturated fatty acids (PUFA) [59]. A variety of markers evidence that AD brain is under high oxidative stress including lipid peroxidation (LPO), as shown by the high brain concentrations of acrolein, MDA (malondialdehyde) or HNE (4hydroxynonenal) [60-62], protein oxidation [60], and nucleic acid oxidation (affecting both DNA [63, 64] and RNA [65]).

The presence of ROS induces the LPO of PUFA, which leads to membrane damage, thus hindering the integrity of the cell, and to the generation of toxic products, which are more stable than ROS, therefore being able to spread the damage to other regions [59, 66]. AD brains show LPO damage localized in the most affected areas being one of the earliest detectable oxidative damage $[59,62,66]$. Furthermore, LPO is tightly related to excessive $A \beta$ production through the upregulation of BACE-1 [66], and, in turn, the increased $A \beta$ production raises the levels of LPO [60], generating a positive feedback.

The two most important toxic by-products generated by LPO are acrolein and HNE [57, 59, 60, 66], known to crosslink with proteins leading to functional impairment and extensive cellular damage $[57,60]$. The toxic effects of these compounds are wide, but important for the pathophysiology of $\mathrm{AD}$. One of the systems affected by these compounds ability to bind proteins is the antioxidant system. Both products conjugate with GSH depleting it $[60,66]$, thus stripping the system of antioxidant power. In the case of acrolein, its GSH conjugate GS-propionaldehyde is still toxic, generating anion superoxide [66]. Furthermore, they inactivate the antioxidant enzymes such as GST (Glutathione-S-transferase), ALDH1 (aldehyde dehydrogenase), ALDH2, TR (thioredoxin reductase), and Trx (thioredoxin) [59, 66]. Therefore, LPO would increase the oxidative stress present in AD. Additionally, both acrolein and HNE inhibit the glucose transporter [59, 62, $66]$, impairing the energy metabolism, and the glutamate transporter, decreasing its reuptake [59, 60, 62, 66]. Glutamate toxicity is a well-described mechanism in $\mathrm{AD}$, the excess glutamate leading to increased intracellular calcium concentrations which, in turn, increase ROS production and, and finally lead to cell death through apoptosis $[60,61]$. Interestingly, the increase of intracellular calcium concentrations is one of the most prominent effects of LPO by-products. This is because the damage in the membranes intrinsic of LPO leads to changes in the neuronal membrane polarization, generating a calcium influx [66]. Changes in calcium homeostasis can also be caused by the HNE-induced impairment of ion-motive ATPase activity [62]. The increase of intracellular calcium is one of the several causes that lead to apoptosis after LPO; however other cellular mechanisms also play their part. HNE is known to interact with cell cycle controlling proteins such as p38 [57] and p53 [66], it can also activate the pro-apoptotic protein caspase-3, and inhibit the NF-kB-dependent activation of the antiapoptotic enzymes Bcl-2 and MnSOD [66]. Through these mechanisms, HNE favors the apoptotic pathway contributing to the neurodegeneration. Additionally, LPO has been seen to activate JNK, inducing apoptosis. This LPO-dependent induction can be either direct or through an LPO-induced increase in $\mathrm{A} \beta$ production [66].

LPO has a role in three of the hallmarks of AD are synaptic loss, the formation of NFTs, and the loss of ChAT activity. Acrolein and HNE can modify several cytoskeleton proteins, affecting synapse maintenance and formation [60, $62,66]$, and tau protein, inducing GSK-3 $\beta$ phosphorylation [62] and rendering it insensitive to dephosphorylation [66], leading, thus, to its oligomerization and to the formation of NFT [60, 62, 66]. Additionally, HNE has proven to bind ChAT leading to its inhibition after in vitro $A \beta$ treatment 
[60, 62, 66]. It is worth noting that HNE, acrolein, and their modified proteins can be found in NFT and senile plaques and are associated with $\varepsilon 4$ allele of ApoE gene [60, 62], linking most of the proposed mechanisms of $\mathrm{AD}$.

\subsubsection{NGF metabolism}

NGF (nerve growth factor) has a key role in the survival of the basal forebrain cholinergic neurons. In $\mathrm{AD}$ brains there is an alteration of its metabolism that leads to higher concentrations of proNGF in opposite of the mature form. This imbalance leads to a higher activation of the $\mathrm{p} 75^{\mathrm{NTR}}$ pathway, which can result in cellular apoptosis. Furthermore, TrkA receptors levels are decreased in cortical and nucleus basalis magnocellularis neurons, generating a deficit in the retrograde transport of NGF to the basal forebrain cholinergic neurons, and, thus, increasing their neurodegeneration. Additionally, some animal models with deficit in NGF have recapitulated part of the AD phenotype, including cholinergic neurodegeneration, cognitive deficits, and amyloid plaque deposition [67].

\subsubsection{Alteration of adult neurogenesis}

Adult neurogenesis is thought to be one of the key factors taking part in neuronal plasticity in response to environmental stimuli [68]. It improves pattern separation and spatial memory [36] and its reduction is associated with aging and $\mathrm{AD}[36,68]$. In $\mathrm{AD}$ animal models there is a decrease in neurogenesis that is present before the appearance of the disease [36]. Numerous animal models of FAD have shown decreased NPC (neuronal progenitor cells) proliferation and neuronal differentiation related to the APPswe mutation and/or PS1 $\triangle \mathrm{E} 9$ (deletion of exon 9 of PSEN-1) [36]. Other genes related to APP such as ApoE have also proven to influence adult neurogenesis, as proven with transgenic mouse models. ApoE4 knock-in models and ApoE knock down models had both impaired adult neurogenesis [36]. Furthermore, neuronal maturation seems to be inhibited through two pathways, on one hand via CDK5 activation by $A \beta$ and on the other through AICD [68]. Tau phosphorylation is tightly related with the neurogenesis deficit, as it accumulates in the neurogenic niches [36]. However, there have been other experiments where the expression of FAD related genes lead to an increased neurogenesis, therefore more research with similar techniques is needed $[36,68]$.

There are less studies performed in humans and most of them are conflicting [36], one study established a relation between the decrease in hippocampal stem cells and ChAT activity, and noted that the decrease in neurogenesis was dependent on several facts such as stage of the disease and neurogenesis niche areas [68]. Furthermore, the effect of the neurogenesis decrease on cognition is not yet fully understood, as there is only a single study where they could correlate neurogenesis decline with contextual fear conditioning [36].

\subsection{Therapeutic approaches in the treatment of} Alzheimer Disease: from anticholinergic drugs to

\section{the secondary prevention of neurodegenerative} diseases

To date, there is no effective therapeutic intervention for $\mathrm{AD}$ [69]. Based on the deficit in cholinergic neurotransmission AChE inhibitors (donepezil, galantamine, rivastigmine) are used in therapeutics to treat mild to moderate $\mathrm{AD}$ in order to restore the cholinergic loss. Other drugs approved are based mainly on observed alterations on neurotransmitter systems as for the $N$-methyl- $D$-aspartate (NMDA) receptor antagonist memantine, and these are mainly used to treat moderate to severe AD [70]. However, these current therapeutic strategies are only symptomatic and the improvements in memory that they provide are temporary, modest, and do not change the disease progression [54]. Even so, the number of clinical trials related to $\mathrm{AD}$ surpasses 1,500 (including over 400 ongoing and more than 1,100 already closed) [71], evidencing a lack of understanding of the multifactorial etiology and high complexity of the underlying mechanisms.

Main efforts today are oriented at the secondary prevention of $\mathrm{AD}$. Nutritional habits, exercise and cognitive stimulation taken in combination may provide protection to neurodegeneration. The modulatory effect of diet on the risk of suffering certain diseases has been widely researched. Although primarily described in cardiovascular diseases, this fact has also been related to neurodegenerative disorders [72]. Epidemiological data suggest that cognitive impairment in general, and $\mathrm{AD}$, in particular, could be prevented by antioxidants, vitamins $\mathrm{E}$ and $\mathrm{B}$, and PUFAs present in wine, vegetables, fruits and fish [17]. As previously mentioned, an imbalance between ROS production and the antioxidant defense system is generally observed in neurodegenerative diseases. The specific evidence of oxidative stress in $\mathrm{AD}$ indicates the potential role that antioxidants such as dietary polyphenols could play in the prevention of these diseases. Polyphenols are secondary metabolites produced by plants that are abundant in fruits, vegetables, olive oil, red wine, and tea. Dietary polyphenols are highly unlikely to provide a direct antioxidant effects mainly because their low dosage and poor bioavailability. Nevertheless, their natural origin and reactivity towards multiple targets in biological systems have highlighted them as interesting compounds to deal with the multifactorial etiology of these diseases [73].

\section{GREEN TEA POLYPHENOLS AND SECONDARY PREVENTION OF ALZHEMIER DISEASE}

Tea is one of the dietary sources of polyphenols and one of the most popular consumed beverages worldwide. Green tea constitutes about $20 \%$ of the world tea production and is mainly consumed in Japan, China, and other Asian countries [74]. It is produced by brewing dried leaves and buds of Camelia sinensis. Green tea consumption has been proposed to have a great variety of beneficial health effects including neuroprotective, anti-carcinogenic, anti-obesogenic, antiatherosclerotic, hypolipidemic, anti-diabetic, antiinflammatory, anti-bacterial, and antiviral [75-77]. However, little epidemiological data are available regarding green tea consumption and cognitive function. The first and only study 
that focuses on the possible relationship between green tea and cognitive impairment was performed in the context of the Tsurugaya project, a comprehensive geriatric assessment of elderly Japanese population. Cognitive function, as measured by the mini-mental state examination (MMSE) score, inversely correlated with green tea consumption. Subjects drinking more than two cups of green tea per day were less cognitively impaired than those drinking only one cup per day or less [78].

All these effects have been attributed to the tea polyphenols, known as catechins. Catechins are components of a more general class of flavonoids, the flavan-3-ols. There are four major catechins present in green tea. In decreasing order of abundance, they are (-)-epigallocatechin-3-gallate (EGCG), (-)-epigallocatechin (EGC), (-)-epicatechin-3gallate (ECG) and (-)-epicatechin (EC) [79] (Figure 2). Two other catechins (gallocatechin and catechin) are considered trace or minor components [80]. EGCG is the most abundant catechin in green tea and it accounts for $50-80 \%$ of the total tea catechins [81]. A normal brewed cup of green tea with $2.5 \mathrm{~g}$ of tea leaves may contain between 130 and $180 \mathrm{mg}$ of EGCG [74]. Besides being the most abundant green tea catechin, EGCG has gathered a lot of attention and is considered the most bioactive tea compound [76].

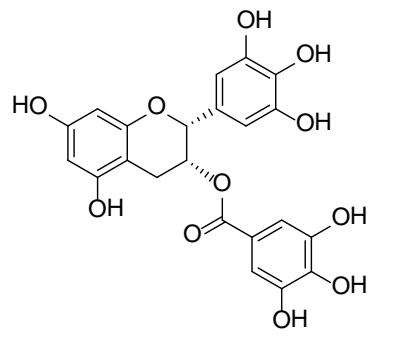

$\left({ }^{-}\right)^{-E p i g a l l o c a t e c h i n-3-g a l l a t e ~}$ (EGCG)<smiles>Oc1cc(O)c2c(c1)O[C@H](c1cc(O)c(O)c(O)c1)[C@H](O)C2</smiles>

()$^{-}$-Epigallocatechin (EGC)

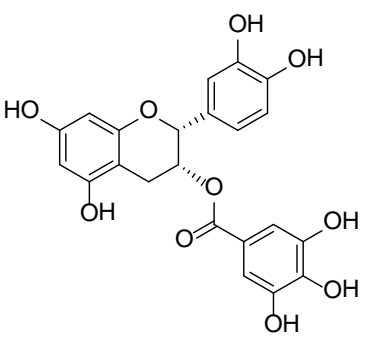

$\left(^{-}\right)^{-E p i c a t e c h i n-3-g a l l a t e ~}$ (ECG)<smiles>Oc1cc(O)c2c(c1)O[C@H](c1ccc(O)c(O)c1)[C@H](O)C2</smiles>

$\left(^{-}\right)^{-E p i c a t e c h i n ~}$ (EC)
Figure 2: Chemical structures of green tea catechins.

\subsection{EGCG general overview of its pharmacokinetics and metabolic disposition}

In experimental studies EGCG has been administered in the form of standardized green tea extracts or as purified EGCG. The extracts result from a water based extraction method, which begins with green tea leaves and then involves successive steps to concentrate the catechins, thought to be responsible for the health benefits of green tea. Polyphenon E (Polyphenon E International) is a green tea catechin-enriched extract that contains $80 \%$ to $98 \%$ total catechins by weight, with EGCG as the main component accounting for $50 \%$ to $75 \%$ of the material. Polyphenon 60 (Sigma Aldrich), with a minimum content of $60 \%$ of total catechins, is also available. Another preparation is the Mega Green Tea Extract (Life Extension) that contains 98\% total polyphenols and 45\% EGCG. These preparations have variable concentrations of caffeine or can be decaffeinated. Highly purified EGCG from green tea extract (95\%) is also available (DSM Nutritional Products, Teavigo). All these products have been assayed in animal models and in humans, and, thus, aspects to take into consideration when looking at the results, are the different dosing protocols used, potential differences in bioavailability, and the interaction of catechins other than EGCG in its bioavailability and elicited effects.

During the last two decades, a great deal of work has been dedicated to the pharmacokinetics of tea catechins. Important advances have also been accomplished in the knowledge of the complex metabolic biotransformation these compounds undergo in animals and humans [82, 83]. Oral bioavailability of EGCG is relatively low possibly due to its gastrointestinal stability, its poor intestinal absorption, and its extensive hepatic and intestinal first-pass metabolism [80]. The phase III metabolism or active efflux carried out by multidrug resistance-associated proteins (MRP) may be involved in EGCG absorption. Evidences from in vitro studies are pending of confirmation in vivo [84]. A number of pharmacokinetic parameters such as the time to achieve maximum plasma concentration $\left(\mathrm{T}_{\max }\right)$ after oral administration (which is about 1-1.5 hours) or the elimination half-life $\left(\mathrm{t}_{1 / 2}\right)$, that fluctuates between 3 and 4 hours [74] were derived from blood and urine EGCG concentrations in humans [85, 86]. Like other gallated flavan-3-ols, EGCG is found in plasma in its non-conjugated form (77-90\%) [76]. Interesting for the potential neuroprotective effects of EGCG, is its ability to distribute into the brain after oral administration both in mice [87] and rats [88].

Green tea catechins undergo several phase II metabolism reactions. The enzymes involved in these reactions are catechol-O-methyltransferase (COMT), UDPglucuronosyltransferases, and sulfotransferases (SULT), which generate a great variety of methylated, glucuronidated, and sulfated metabolites, respectively [81, 84]. Additionally, three ring-fission metabolites that are produced by colonic microbiota have also been identified in human urine and plasma following green tea intake [79]. The chemical structure of EGCG and the positions at where the main metabolic reactions take place are represented in Figure 3. 


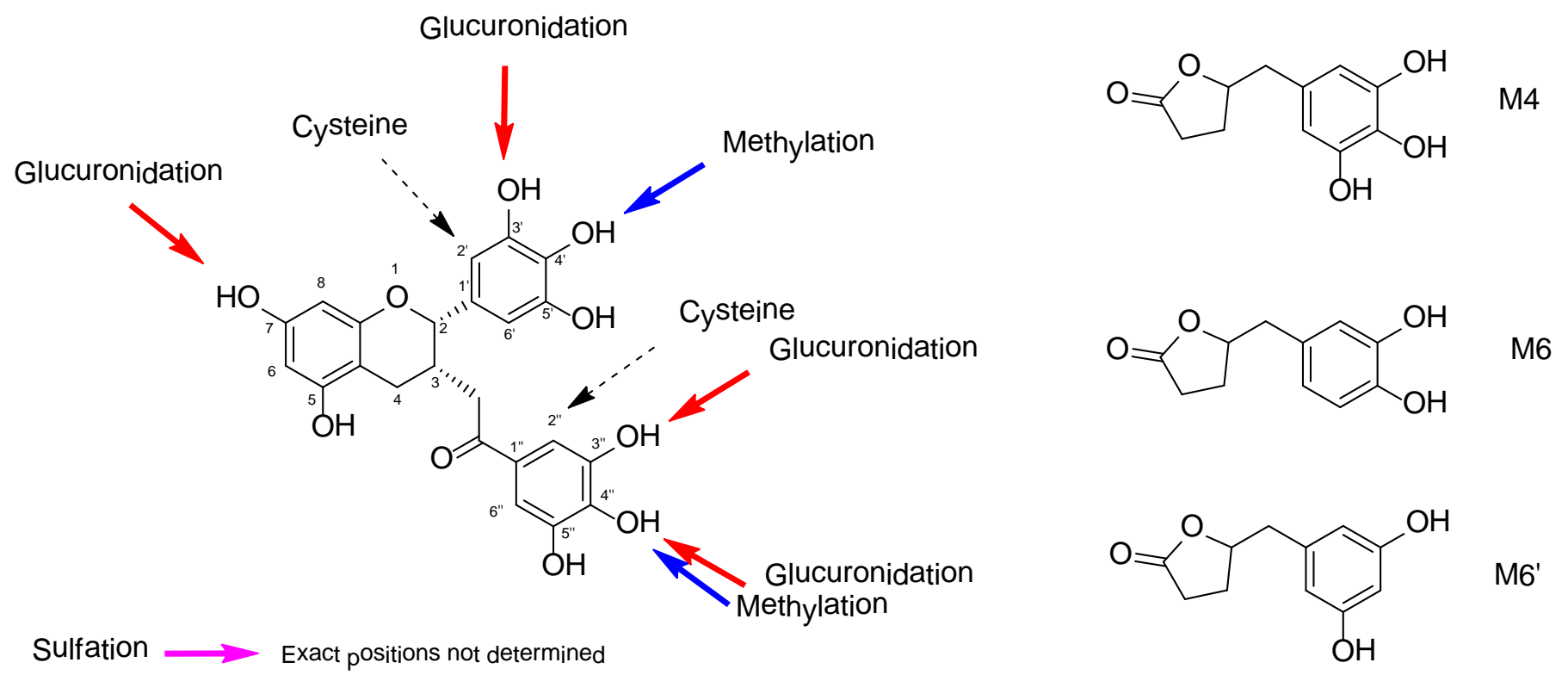

Figure 3: Representation of the chemical structure of EGCG indicating the positions where the main metabolic reactions (methylation, glucuronidation, sulfation) take place. Three ring-fission metabolites (M4, M6 and M6') produced by colonic microbiota have also been identified after green tea intake. Cysteinyl conjugates have been found in mice urine samples but not in humans. M4, (-)-5-(3',4',5'-trihydroxyphenyl)- $\gamma$-valerolactone; M6, (-)-5-(3',4'dihydroxyphenyl)- $\gamma$-valerolactone; M6', (-)-5-(3’,5’-dihydroxyphenyl)- $\gamma$-valerolactone.

Enzymes implicated in these reactions are catechol methyltransferase (COMT), UDP-glucuronosyl transferase (UDPGT), and sulfotransferase (SULT). COMT catalyzed EGCG methylation has been observed in vivo in humans, mice, and rats [79]. The positions where this reaction takes place are 4'" and 4' leading to the monomethylated 4'-Omethyl-EGCG and the bismethylated 4',4''-di-O-methylEGCG. Most EGCG metabolites are biologically inactive, except for methylated metabolites, which can display biological activity through mechanisms other than those attributed to EGCG [89, 90].

\subsection{Potential beneficial effects of EGCG in AD}

EGCG has received significant attention as a therapeutic agent due to its multiple mechanisms of action that may target several of the multifactorial mechanisms underlying neurodegeneration in $\mathrm{AD}$. Although the first described mechanisms included free radical scavenging, iron-chelating, and anti-inflammatory activities, current scientific knowledge has demonstrated other intracellular molecular targets behind EGCG mechanism of action [91]. EGCG is involved in the regulation of calcium homeostasis, the modulation of different kinases (including MAPK, AKT and PKC activation, and DYRK1A inhibition), the induction of multiple phase II detoxifying enzymes via Nrf2 activation, [92] and the activation of cell cycle genes. EGCG is also involved in the processing of APP through the modulation of different secretase activities such as ADAM10 or BACE-1.

The potential beneficial effects in the context of $\mathrm{AD}$ have been studied in detail both in cell and animal models, allowing a deeper understanding of EGCG actions on the molecular cascades and biochemistry, as well as on cognition. Different cell lines have been used to this end (summarized in Table 2). The proposed mechanisms that will be examined in this review include: neuroprotection, neurorescue, protection against oxidative stress, protection against neuroinflammation, promotion of the nonamyloidogenic pathway, inhibition of the amyloidogenic pathway and other effects.

Cell studies have been complemented with animal model studies, in which there is the possibility of evaluating the EGCG effects on cognition and correlate them afterwards with molecular data. Several studies have been performed in different AD models both in rats and mice. Animal studies can be divided into two groups: those that use chemicallyinduced AD models (like LPS or $A \beta$ ) and those that use either aged animals or transgenic models of aging or $A D$ including models expressing amyloid precursor protein (APP) Tg2576, APP/presenilin 1, 3xAD, single h-Tau, and models of physiological aging. Genetically modified and aged mice provide a closer model to human AD pathology (familial and sporadic) than induced models. The use of transgenic models expressing human APP is widely extended, despite rodent APP being less prone to aggregate as well as to be cleaved by $\beta$-secretases [33]. All transgenic mouse models are based on familiar AD mutations, mainly because the causes of sporadic $\mathrm{AD}$ are not yet fully understood. For this reason, there is not a mouse model that exhibits all the alterations seen in human $\mathrm{AD}$, but rather several mouse models that allow studying several aspects of the disease in isolation. APP transgenic mouse models do recapitulate most of the signs of the disease, including plaque formation and memory impairment, but they do not have NFT despite having increased tau phosphorylation. To obtain NFT in AD mouse models there is a need to breed multitransgenic mouse models with mutated tau. Other 
aspects that are also different in mouse models are neuroinflammation and neuronal cell loss. These differences could be due to the time course of the disease that is shorter in mice than in humans [93]. All the results from animal models are summarized in Table 3a (for EGCG) and $\mathbf{3 b}$ (for other flavonoids), and are further explained below.

\subsubsection{Neuroprotection}

Neuroprotection is the most widely studied beneficial effect of EGCG. This action is mostly associated to the reduction of $A \beta$-induced toxicity. Experiments performed in several cell lines (PC12 and SK-N.MC) that were preincubated with different concentrations of EGCG showed a decrease in the cell death induced by the addition of both aggregated and monomeric $A \beta$ forms [94, 95]. This antiapoptotic effect was also seen in cortical primary mice cells co-treated with varying doses of EGCG and $20 \mu \mathrm{M}$ $\mathrm{A} \beta_{25-35}$ [96]. In a different experiment rat cortical neurons, pretreatment of with $10 \mu \mathrm{M}$ EGCG for 30 minutes before adding $1 \mu \mathrm{M}$ of oligomeric $\mathrm{A} \beta$, prevented both the mitochondrial dysfunction and the inhibition of NMDAinduced $\mathrm{Ca}^{2+}$ influx triggered by $\mathrm{A} \beta$ shedding light into possible mechanisms [97]. Recent research has pointed out to a specific pathway that could be responsible of the neuroprotective effects of EGCG. These experiments, performed in rat cortical neurons, showed that the antiapoptotic effect of EGCG was due to the activation of the $\alpha 7 \mathrm{nAChR}$ pathway, as the blockade of $\alpha 7 \mathrm{nAChR}$ prevented the beneficial effects observed including increased viability, decreased DNA fragmentation, and decreased ROS production (Pathway included in Figure 4) [98]. Thus, EGCG-driven neuroprotection can prevent cell death induced by $\mathrm{A} \beta$, in vitro.

The results of the cell models experiments, led to in vivo preclinical trials. In rats, oral administration of $5 \mathrm{~g} / \mathrm{L}$ of the green tea extract Polyphenon E (PE) in drinking water prevented the induction of $\mathrm{AD}$ phenotypes through a cerebral infusion of $A \beta_{1-40}$, such as the increase in working and reference memory errors caused by $A \beta_{1-40}$, as assessed through radial maze [99]. Two sets of experiments induced $\mathrm{AD}$ in mice through intracerebroventricular (i.c.v.) administration of LPS or A $\beta_{1-42}$ after a 3-week oral pretreatment with EGCG. Behavioral testing in the Morris Water Maze (MWM), a spatial learning hippocampal dependent test and in the passive avoidance test, that measures cholinergic-dependent recent memory, which is one of the early signs of AD-dementia, showed an improving effect of EGCG, suggesting a protective effect against LPS and $A \beta_{1-42}[100,101]$ toxicity. One of the latest published results also explored the interaction between EGCG and voluntary exercise. Both EGCG alone and the combined treatment showed improved performance in the nest building behavior, indicative of executive function and the Barnes maze, a more complex version of the MWM, in the TgCRND8 model of AD [102]. However, it is worth noting that neuroprotective activity is possibly of little importance when the disease has already started, but can be regarded as prevention.

\subsubsection{Neurorescue}

EGCG treatment is not only preventive through protection against neurotoxicity but has also rescuing activity. Therefore, acting after the damage has started is also possible. Experiments using different insults in PC12 cells have shown the capacity of EGCG to rescue cell viability once the damage has already started [94]. In serum withdrawal conditions, EGCG could improve toxicity hallmarks through the activation and membrane translocation of PKC $\alpha$, which inhibits the pro-apoptotic enzymes caspase3, PARP, and Bad [103]. The same results regarding cell viability were replicated in a different experiment using MC65 -a neuroblastoma derived cell line overexpressing APP-C99 in an inducible manner. This anti-apoptotic effect was due to the inhibition of c-Abl-FE65 (c-Abl oncogene and amyloid $\beta$ precursor protein-binding, family $B$ member 1). $\mathrm{c}-\mathrm{Abl}$ translocates to the nucleus under $\mathrm{A} \beta$ overproduction where it induces apoptosis, this translocation being dependent on the interaction of c-Abl and FE65. Furthermore, the inhibition of this interaction also leads to a decreased GSK-3 $\beta$ phosphorylation potentially reducing tau phosphorylation (Schematic representations of the pathways included in Figure 4) [95]. EGCG use in transgenic mouse models confirmed its ability to rescue damaged tissues. Most of the animals used in these experiments were old animals with an already established AD. Rezai-Zadeh administered intraperitoneal (i.p.) EGCG $20 \mathrm{mg} / \mathrm{kg}$ for 60 days to aged Tg2576 mice -overexpressing Swedish mutant of APPbefore behavioral testing in radial arm water maze (RAWM), which is particularly sensitive to the cognitive effects of $A \beta$ accumulation in the brain [104], and found an EGCGinduced working memory improvement [105]. Similar results were observed in working and reference memory in the MWM test after 4-month oral administration. Molecular analysis of the brain lysates manifested a decreased interaction of c-Abl and FE65 in accordance with the in vitro results. The authors suggested that this interaction could contribute to the reduction of spatial memory retention displayed by these transgenic mice [95]. Furthermore, oral administration of green tea extract during 6 months in two different mouse models of aging, the aged C57BL/6J, and the SAMP8 (Senescence-accelerated prone) mouse, improved their performance in the MWM test reducing the escape latency during the learning phase and increasing the time spent in the target quadrant, as well as the number of platform crossings during the reference memory probe trial. Both models presented increases in PKA/CREB pathway, along with increments in the synaptic-plasticity related proteins PSD95, BDNF, and CamKII, which would explain the improvement in long-term memory, LTP (long term potentiation), and synaptic function observed in the behavioral testing (Figure 4) [106, 107]. PS2, a completely different aging mouse model overexpressing hPS2m (human presenilin 2) was also administered with EGCG for 1 week and showed identical results on the MWM [100]. Similarly, EGCG proved to be able to rescue hippocampal-dependent learning and memory deterioration of cholinergic-dependent recent memory in the double transgenic mice APPswe/PS1 $\triangle E 9$ [108] .These improvements were paired with a decrease in hippocampal APP protein and decreased $\mathrm{A} \beta_{1-40}$ plaque burden. Interestingly, these results were linked 
Table 2. Studies of EGCG effects in cellular models

\begin{tabular}{|c|c|c|c|c|c|c|}
\hline Authors & Cell model & $\begin{array}{l}\text { EGCG: } \\
\text { Concentration and } \\
\text { treatment time }\end{array}$ & Toxic agent & Results & Mechanisms of action & Conclusions \\
\hline \multirow{6}{*}{$\begin{array}{l}\text { Levites, Y. et } \\
\text { al } 2003\end{array}$} & SH-SY5Y & \multirow{2}{*}{$\begin{array}{l}0.1,1,5 \text { and } 10 \mu \mathrm{M} \\
2 \text { hours }\end{array}$} & - & \multirow[t]{2}{*}{$\uparrow \mathrm{sAPP} \alpha$ release } & \multirow{6}{*}{$\begin{array}{l}\text { Activation of } \alpha \text {-secretase through } \\
\text { PKC }\end{array}$} & \multirow{2}{*}{$\begin{array}{l}\text { Promotion of the non-amyloidogenic } \\
\text { pathway }\end{array}$} \\
\hline & \multirow[t]{5}{*}{ PC12 } & & - & & & \\
\hline & & $1 \mu \mathrm{M}$ & \multirow{4}{*}{$\begin{array}{l}\text { Aggregated } 10 \\
\mu \mathrm{M} A \beta_{25-35} \\
\mathrm{~A} \beta_{1-42} \text { or } \mathrm{A} \beta_{1-40} \\
48 \text { hours }\end{array}$} & \multirow[t]{4}{*}{$\uparrow$ cell survival } & & \multirow[t]{2}{*}{ Protection against $A \beta$ toxicity } \\
\hline & & $\begin{array}{l}30 \text { min } \\
\text { preincubation }\end{array}$ & & & & \\
\hline & & 0.1 and $1 \mu \mathrm{M}$ & & & & \multirow[t]{2}{*}{ Neurorescue } \\
\hline & & 2 hours after $A \beta_{25-35}$ & & & & \\
\hline \multirow{5}{*}{$\begin{array}{l}\text { Reznichenko, } \\
\text { L. et al } 2005\end{array}$} & \multirow[t]{5}{*}{ PC12 } & 0.1 and $1 \mu \mathrm{M}$ & \multirow{3}{*}{$\begin{array}{l}\text { Serum } \\
\text { withdrawal }\end{array}$} & $\downarrow$ cell mortality & \multirow{3}{*}{$\begin{array}{l}\text { PKC activation and translocation } \\
\text { to membrane (reduction of } \\
\text { caspase- } 3 \text { and PARP cleavage, } \\
\text { and Bad levels) }\end{array}$} & \multirow[t]{3}{*}{ Neurorescue } \\
\hline & & \multirow{2}{*}{$\begin{array}{l}24 \text { hours after } 24 \\
\text { hours of serum } \\
\text { withdrawal }\end{array}$} & & $\begin{array}{l}\text { Rescue of cell body and } \\
\text { neurites retraction }\end{array}$ & & \\
\hline & & & & $\begin{array}{l}\text { Promotion of neurite } \\
\text { outgrowth }\end{array}$ & & \\
\hline & & \multirow[t]{2}{*}{$\begin{array}{l}0.1-1 \mu \mathrm{M} \text { every } 2 \\
\text { days for up to } 4 \text { days }\end{array}$} & \multirow[t]{2}{*}{-} & $\begin{array}{l}\text { Larger cell bodies and } \\
\text { neurite network }\end{array}$ & & \multirow[t]{2}{*}{ Promotion of neuronal differentiation } \\
\hline & & & & $\uparrow$ neurite length & & \\
\hline \multirow[t]{3}{*}{$\begin{array}{l}\text { Rezai-Zadeh, } \\
\text { K. et al } 2005\end{array}$} & \multirow[t]{2}{*}{ SweAPP N2a } & \multirow[t]{3}{*}{$\begin{array}{l}5,10,20,40 \text { and } 80 \\
\mu \mathrm{M}\end{array}$} & \multirow[t]{2}{*}{-} & $\uparrow \alpha-\mathrm{CTF}, \mathrm{sAPP} \alpha$ & Activation of $\alpha$-secretase & $\begin{array}{l}\text { Promotion of the non-amyloidogenic } \\
\text { pathway }\end{array}$ \\
\hline & & & & \multirow{2}{*}{$\downarrow A \beta_{1-42}$ and $A \beta_{1-40}$} & \multirow[t]{2}{*}{ Activation of $\alpha$-secretase } & \multirow[t]{2}{*}{$\begin{array}{l}\text { Promotion of the non-amyloidogenic } \\
\text { pathway }\end{array}$} \\
\hline & $\begin{array}{l}\text { Tg2576 primary } \\
\text { neuronal cultures }\end{array}$ & & - & & & \\
\hline
\end{tabular}




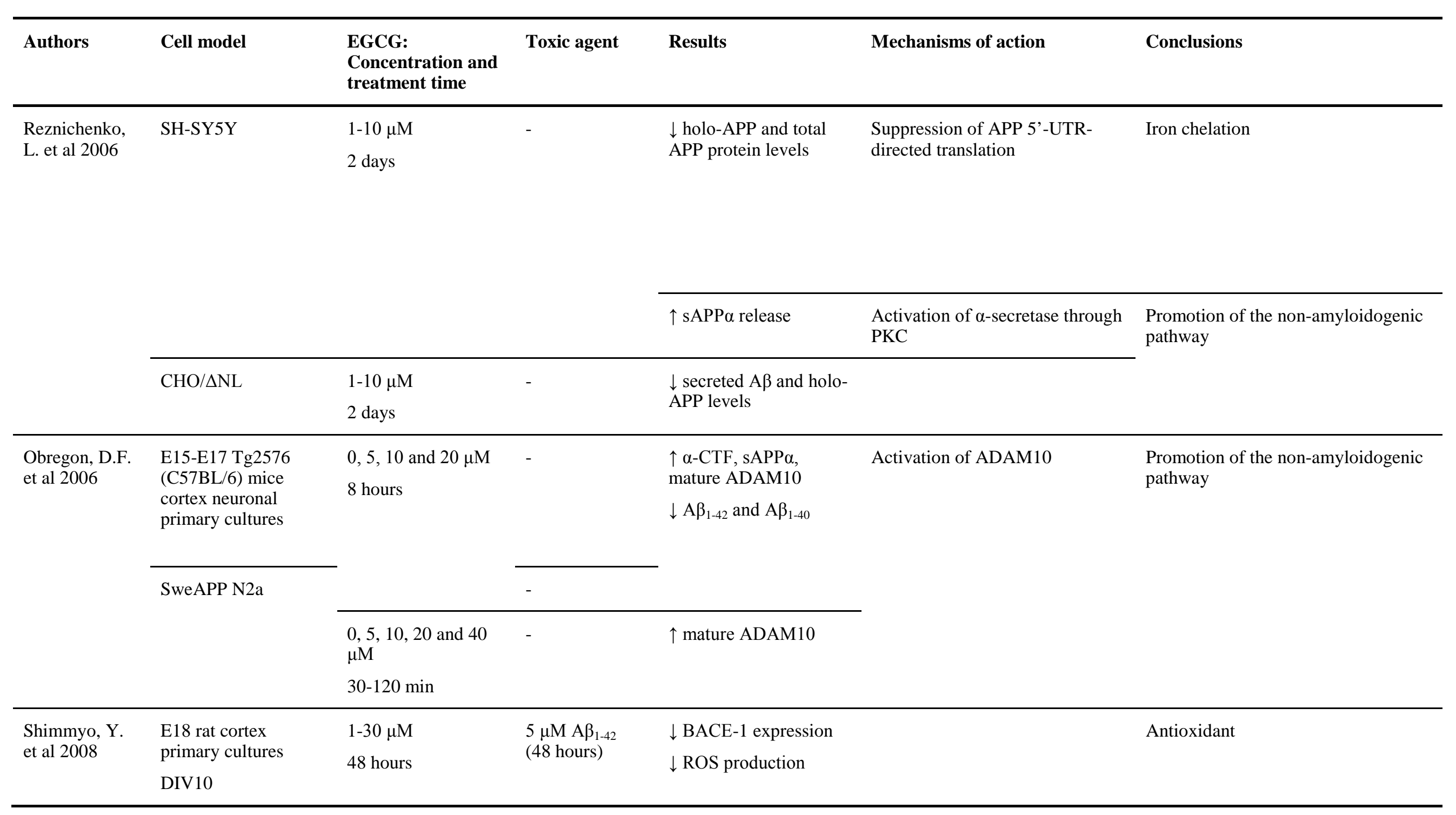




\begin{tabular}{|c|c|c|c|c|c|c|}
\hline Authors & Cell model & $\begin{array}{l}\text { EGCG: } \\
\text { Concentration and } \\
\text { treatment time }\end{array}$ & Toxic agent & Results & Mechanisms of action & Conclusions \\
\hline \multirow[t]{4}{*}{$\begin{array}{l}\text { Lin, C-L. et al } \\
2009\end{array}$} & \multirow[t]{3}{*}{$\begin{array}{l}\text { MC65 (SK-N-MC } \\
\text { transfected with APP- } \\
\text { C99 (inducible)) }\end{array}$} & \multirow[t]{3}{*}{$0,5,10$ and $20 \mu \mathrm{M}$} & - & $\uparrow$ cell viability & $\begin{array}{l}\text { Inhibition of c-Abl-FE65 } \\
\text { interaction, c-Abl nuclear } \\
\text { translocation and GSK-3 } \\
\text { phosphorylation }\end{array}$ & Neurorescue \\
\hline & & & - & $\begin{array}{l}\downarrow \mathrm{A} \beta \text { generation } \\
\uparrow \mathrm{sAPP} \alpha \text { release }\end{array}$ & Activation of $\alpha$-secretase & $\begin{array}{l}\text { Promotion of the non-amyloidogenic } \\
\text { pathway }\end{array}$ \\
\hline & & & - & $\downarrow$ ROS production & & Antioxidant activity \\
\hline & SK-N-MC & $0,5,10$ and $20 \mu \mathrm{M}$ & $\begin{array}{l}5 \mu \mathrm{M} \mathrm{A} \beta_{1-42} \text { or } \\
\mathrm{A} \beta_{1-40} \text { fibrils. } \\
\text { ( } 24-48 \text { hours) }\end{array}$ & $\downarrow$ decrease in cell death & & Protection against $A \beta$ neurotoxicity \\
\hline \multirow{2}{*}{$\begin{array}{l}\text { Romeo, L. et al } \\
2009\end{array}$} & \multirow{2}{*}{$\begin{array}{l}\text { H19-7 (rat } \\
\text { hippocampal } \\
\text { neurons) }\end{array}$} & $25 \mu \mathrm{M}$ & \multirow{2}{*}{$\begin{array}{l}50 \mathrm{mU} / \mathrm{mL} \\
\text { GOX ( } 2 \text { hours) }\end{array}$} & \multirow[t]{2}{*}{$\uparrow$ cell viability } & \multirow[t]{2}{*}{ HO-1 upregulation through Nrf2 } & \multirow{2}{*}{$\begin{array}{l}\text { Neuroprotection against oxidative } \\
\text { stress }\end{array}$} \\
\hline & & $\begin{array}{l}12 \text { hours } \\
\text { pretreatment }\end{array}$ & & & & \\
\hline \multirow{4}{*}{$\begin{array}{l}\text { He, Y. et al } \\
2011\end{array}$} & \multirow{4}{*}{$\begin{array}{l}\text { E17 rat cortex } \\
\text { primary neurons } \\
\text { (Sprague-Dawley) } \\
\text { DIV8 }\end{array}$} & \multirow{4}{*}{$\begin{array}{l}10 \mu \mathrm{M} \\
30 \text { minutes } \\
\text { pretreatment }\end{array}$} & \multirow{4}{*}{$\begin{array}{l}1 \mu \mathrm{M} \\
\text { oligomeric } \mathrm{A} \beta \\
\text { (16 hours) }\end{array}$} & Prevention of & & \multirow[t]{4}{*}{ Protection against $A \beta$ neurotoxicity } \\
\hline & & & & $\begin{array}{l}\text { mitochondrial } \\
\text { dysfunction }\end{array}$ & & \\
\hline & & & & $\begin{array}{l}\text { Prevention of the } \\
\text { inhibition of the } \\
\text { NMDA-induced } \mathrm{Ca}^{2+} \\
\text { influx }\end{array}$ & & \\
\hline & & & & $\begin{array}{l}\text { Prevention of ROS } \\
\text { production }\end{array}$ & & \\
\hline \multirow[t]{2}{*}{$\begin{array}{l}\text { Wang, Y. et al } \\
2012\end{array}$} & $\begin{array}{l}\text { Adult ( } 8-10 \text { weeks) } \\
\text { mouse NPCs }\end{array}$ & $\begin{array}{l}0,5,10,20 \text { and } 40 \\
\mu \mathrm{M}\end{array}$ & \multirow[t]{2}{*}{-} & \multirow[t]{2}{*}{$\uparrow$ proliferation } & \multirow[t]{2}{*}{$\begin{array}{l}\text { Upregulation of Shh, Ptc and } \\
\text { Gli1 }\end{array}$} & \multirow[t]{2}{*}{ Promotion of adult neurogenesis } \\
\hline & (C57BL/6J) & 24 hours & & & & \\
\hline
\end{tabular}




\begin{tabular}{|c|c|c|c|c|c|c|}
\hline Authors & Cell model & $\begin{array}{l}\text { EGCG: } \\
\text { Concentration and } \\
\text { treatment time }\end{array}$ & Toxic agent & Results & Mechanisms of action & Conclusions \\
\hline $\begin{array}{l}\text { Lee, Y.J. et al } \\
2013\end{array}$ & $\begin{array}{l}\mathrm{P} 2 \text { rat astrocyte } \\
\text { primary culture }\end{array}$ & 10,20 and $50 \mu \mathrm{M}$ & LPS $1 \mu \mathrm{g} / \mathrm{mL}$ & $\begin{array}{l}\downarrow \text { iNOS and COX2 } \\
\downarrow \mathrm{BACE}, \mathrm{C} 99 \text { and APP }\end{array}$ & $\begin{array}{l}\text { Inhibition of the upregulation of } \\
\text { M-CSF, ICAM-1, IL-16 and } \\
\text { other cytokines }\end{array}$ & Anti-neuroinflammatory activity \\
\hline $\begin{array}{l}\text { Rushworth, } \\
\text { J.V. et al } 2013\end{array}$ & SH-SY5Y & - & $\begin{array}{l}\text { Fibrillar A } \beta \\
\text { untreated or } \\
\text { treated with } \\
\text { EGCG }\end{array}$ & $\begin{array}{l}\downarrow \text { binding of } A \beta \\
\text { oligomers to PrPc } \\
\text { Prevention of } A \beta \\
\text { induced death }\end{array}$ & & Protection against $A \beta$ neurotoxicity \\
\hline $\begin{array}{l}\text { Zhang, X. et al } \\
2013\end{array}$ & $\begin{array}{l}\text { E16-E18 rat cortical } \\
\text { neurons primary } \\
\text { culture }\end{array}$ & $\begin{array}{l}\text { 5-100 } \mu \mathrm{M} \\
\text { Optimal } \\
\text { concentration: } 80 \\
\mu \mathrm{M}\end{array}$ & $\begin{array}{l}\mathrm{A} \beta_{1-42} 25 \mu \mathrm{M} \\
\text { (24 hours) }\end{array}$ & $\begin{array}{l}\uparrow \text { viability } \\
\downarrow \text { DNA fragmentation } \\
\downarrow \text { caspase-3 } \\
\downarrow \text { ROS } \\
\uparrow \text { antiapoptotic } \\
\text { signaling }\end{array}$ & $\begin{array}{l}\text { Activation of } \alpha 7 \mathrm{nAChR} \text { pathway, } \\
\text { including PI3K, Akt, and Bcl-2 }\end{array}$ & Protection against $A \beta$ neurotoxicity \\
\hline $\begin{array}{l}\text { Gundimeda, U. } \\
\text { et al } 2014\end{array}$ & PC12 (TrkB) & $\begin{array}{l}\text { GTPP } 0.05-5 \mu \mathrm{g} / \mathrm{mL} \\
\text { or EGCG } 0.25-5 \mu \mathrm{M} \\
+ \text { BDNF }(2-50 \\
\mu \mathrm{g} / \mathrm{mL}) \\
3 \text { days }\end{array}$ & - & $\begin{array}{l}\text { Potentiation of the } \\
\text { neurite outgrowth } \\
\text { produced by low } \\
\text { concentrations of } \\
\text { BDNF }\end{array}$ & $\begin{array}{l}\text { Interaction with 67LR receptor. } \\
\text { Dependent on } \mathrm{H}_{2} \mathrm{O}_{2} \text { production. }\end{array}$ & Neuritogenesis \\
\hline $\begin{array}{l}\text { Choi, S-M. et } \\
\text { al } 2014\end{array}$ & $\begin{array}{l}\text { E15-E17 mice } \\
\text { cortical neurons } \\
\text { primary culture on } \\
\text { glia } \\
\text { DIV 13-14 }\end{array}$ & $\begin{array}{l}3,10 \text { or } 30 \mu \mathrm{M} \\
24 \text { or } 48 \text { hours }\end{array}$ & $\begin{array}{l}\mathrm{A} \beta_{25-35} 20 \mu \mathrm{M} \\
\text { (24 or } 48 \text { hours) }\end{array}$ & $\begin{array}{l}\downarrow \text { LDH release }=\downarrow \\
\text { neuronal cell death }\end{array}$ & & Protection against $A \beta$ neurotoxicity \\
\hline
\end{tabular}

67LR: laminin receptor; $\alpha 7 \mathrm{nAChR}: \alpha 7$ nicotinic acetylcholine receptor; Aß: amyloid beta; ADAM10: a desintegrin and metalloprotease domain 10; Akt: proto-oncogen c-Akt; APP: amyloid precursor protein; $\alpha$-CTF: alpha C-terminal fragment of APP; BACE-1: beta-site APP-cleaving enzyme 1; Bad: Bcl2-associated agonist of cell death; Bcl-2: B-cell CLL/lymphoma 2; c-Abl: c-abl oncogene 1; COX-2: cytochrome C oxidase 2; DIV: Day In Vitro; E: embryonic day; FE65: APBB1 - amyloid beta (A4) precursor protein-binding, family B, member 1; GOX: glucose oxidase; GSK-3ß: glycogen synthase kinase 3 beta; GTPP: green tea polyphenols; HO-1: HMOX1 heme oxygenase (decycling) 1; holo-APP: amyloid precursor protein holoprotein; ICAM-1: intracellular adhesion molecule 1; IL-16: interleukin 16; iNOS: inducible nitric oxide synthase; LDH: lactate dehydrogenase; LPS: lipopolysaccharide; M-CSF: macrophage colony-stimulating factor; NMDA: N-methyl-D-aspartic-acid; Nrf2: nuclear factor (erythroid-derived 2)-like 2; NPC: neuronal progenitor cell; P: postnatal day; PARP: poly ADP-ribose-polymerase; PIeK: phosphoinositide 3-kinase; PKC: protein kinase C; Ptc: patched; ROS: reactive oxygen species; sAPPa: soluble amyloid precursor protein alpha; Shh: Sonic hedgehog; TrkB: neurotrophic tyrosine kinase, receptor, type 2. 
Table 3a: Summary of in vivo experiments with EGCG

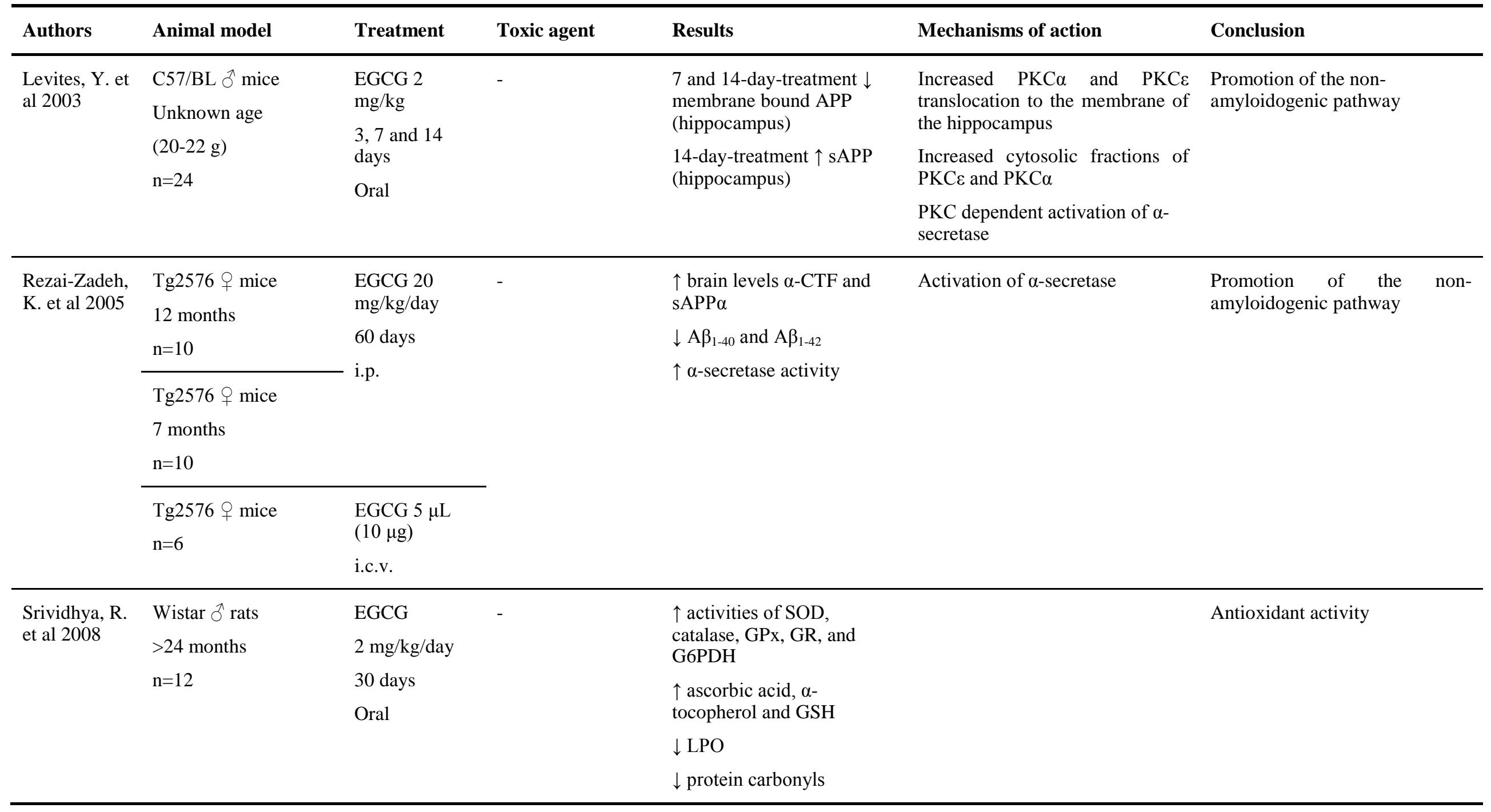




\begin{tabular}{|c|c|c|c|c|c|c|}
\hline Authors & Animal model & Treatment & Toxic agent & Results & Mechanisms of action & Conclusion \\
\hline \multirow[t]{11}{*}{$\begin{array}{l}\text { Rezai-Zadeh, } \\
\text { K. et al } 2008\end{array}$} & \multirow{6}{*}{$\begin{array}{l}\mathrm{Tg} 2576 \text { q mice } \\
\text { (B6/SJL) } \\
8 \text { months } \\
\mathrm{n}=20\end{array}$} & \multirow{6}{*}{$\begin{array}{l}\text { EGCG } 50 \\
\mathrm{mg} / \mathrm{kg} \\
6 \text { months } \\
\text { Oral }\end{array}$} & \multirow[t]{6}{*}{-} & $\begin{array}{l}\downarrow \mathrm{A} \beta \text { deposition in } \\
\text { cingulated cortex, }\end{array}$ & \multirow[t]{5}{*}{ Activation of $\alpha$-secretase } & \multirow[t]{5}{*}{$\begin{array}{l}\text { Promotion of the non- } \\
\text { amyloidogenic pathway }\end{array}$} \\
\hline & & & & $\begin{array}{l}\text { hippocampus and } \\
\text { entorhinal cortex }\end{array}$ & & \\
\hline & & & & $\begin{array}{l}\downarrow \text { soluble and insoluble } A \beta_{1-} \\
40 \text { and } A \beta_{1-42}\end{array}$ & & \\
\hline & & & & $\uparrow$ ADAM10 maturation & & \\
\hline & & & & $\uparrow \mathrm{sAPP} \alpha$ release & & \\
\hline & & & & $\begin{array}{l}\downarrow \text { sarksoyl-soluble phospho- } \\
\text { tau }\end{array}$ & & Neuroprotection \\
\hline & \multirow{5}{*}{$\begin{array}{l}\text { Tg2576 } 9 \text { mice } \\
\text { (mixed background } \\
\text { C57/B6/SJL/Swiss- } \\
\text { Webster) } \\
12 \text { months } \\
\mathrm{n}=10\end{array}$} & \multirow{5}{*}{$\begin{array}{l}\text { EGCG } 20 \\
\mathrm{mg} / \mathrm{kg} \\
60 \text { days } \\
\text { i.p. }\end{array}$} & \multirow[t]{5}{*}{-} & \multirow[t]{5}{*}{$\begin{array}{l}\text { Improved working memory } \\
\text { in the RAWM }\end{array}$} & & \multirow[t]{2}{*}{$\begin{array}{l}\text { Promotion of the non- } \\
\text { amyloidogenic pathway }\end{array}$} \\
\hline & & & & & & \\
\hline & & & & & & \multirow{3}{*}{$\begin{array}{l}\text { Reduction in brain oxidative } \\
\text { stress }\end{array}$} \\
\hline & & & & & & \\
\hline & & & & & & \\
\hline \multirow[t]{4}{*}{$\begin{array}{l}\text { Lin, C-L. et } \\
\text { al } 2009\end{array}$} & \multirow{4}{*}{$\begin{array}{l}\text { Tg2576 (C57BL/6) } \\
\text { mice } \\
8 \text { months } \\
\mathrm{n}=35\end{array}$} & \multirow{4}{*}{$\begin{array}{l}\text { EGCG } 20 \\
\mathrm{mg} / \mathrm{kg} / \text { day } \\
4 \text { months } \\
\text { Oral }\end{array}$} & \multirow[t]{4}{*}{-} & $\begin{array}{l}\downarrow \text { hippocampal } \mathrm{A} \beta_{1-40} \text { and } \\
\mathrm{A} \beta_{1-42}\end{array}$ & Activation of $\alpha$-secretase & \multirow[t]{2}{*}{$\begin{array}{l}\text { Promotion of the non- } \\
\text { amyloidogenic pathway }\end{array}$} \\
\hline & & & & $\downarrow$ number $\mathrm{A} \beta$ plaques & & \\
\hline & & & & $\downarrow$ GSK-3 $\beta$ phosphorylation & Inhibition of c-Abl-FE65 & Protection against $A \beta$ \\
\hline & & & & $\begin{array}{l}\text { Better escape latency in } \\
\text { MWM }\end{array}$ & $\begin{array}{l}\text { interaction and c-Abl nuclear } \\
\text { translocation }\end{array}$ & neurotoxicity \\
\hline
\end{tabular}




\begin{tabular}{|c|c|c|c|c|c|c|}
\hline Authors & Animal model & Treatment & Toxic agent & Results & Mechanisms of action & Conclusions \\
\hline \multirow{6}{*}{$\begin{array}{l}\text { Lee, Y.K. et } \\
\text { al } 2009\end{array}$} & \multirow{6}{*}{$\begin{array}{l}\text { IcrTacSam:ICR }{ }^{\lambda} \\
\text { mice } \\
5 \text { weeks } \\
n=40\end{array}$} & \multirow{6}{*}{$\begin{array}{l}\text { EGCG } \\
1.5-3 \mathrm{mg} / \mathrm{kg} \\
3 \text { weeks } \\
\text { Oral }\end{array}$} & \multirow{6}{*}{$\begin{array}{l}1 \mu \mathrm{g} \text { LPS } \\
\text { i.c.v. }\end{array}$} & \multirow{2}{*}{\multicolumn{2}{|c|}{$\begin{array}{l}\text { Prevention of PAP and } \\
\text { MWM impairment induced } \\
\text { by LPS }\end{array}$}} & \multirow{2}{*}{$\begin{array}{l}\text { Prevention of the cognitive } \\
\text { decline }\end{array}$} \\
\hline & & & & & & \\
\hline & & & & \multirow{2}{*}{$\begin{array}{l}\downarrow \text { cortical and hippocampal } \\
\mathrm{A} \beta_{1-42} \text { levels, and } A \beta_{1-42} \\
\text { and C99 expression }\end{array}$} & $\begin{array}{l}\text { Decreased } \beta \text { - and } \gamma \text {-secretase } \\
\text { activities in the cortex }\end{array}$ & \multirow[t]{2}{*}{$\begin{array}{l}\text { Inhibition of the amyloidogenic } \\
\text { pathway }\end{array}$} \\
\hline & & & & & $\begin{array}{l}\text { Decreased } \gamma \text {-secretase activity in } \\
\text { the hippocampus }\end{array}$ & \\
\hline & & & & $\downarrow$ GFAP immunoreactivity & $\begin{array}{l}\text { Prevention of the induction of } \\
\text { iNOS and COX-2 }\end{array}$ & Anti-neuroinflammatory activity \\
\hline & & & & $\downarrow$ apoptosis & & Antiapoptotic activity \\
\hline \multirow{8}{*}{$\begin{array}{l}\text { Lee, J.W. et } \\
\text { al } 2009\end{array}$} & \multirow{5}{*}{$\begin{array}{l}\text { IcrTacSam:ICR }{ }^{\lambda} \\
\text { mice } \\
\text { 5-weeks } \\
\mathrm{n}=10\end{array}$} & \multirow{5}{*}{$\begin{array}{l}\text { EGCG } \\
1.5-3 \mathrm{mg} / \mathrm{kg} \\
3 \text { weeks } \\
\text { Oral }\end{array}$} & \multirow{5}{*}{$\begin{array}{l}0.5 \mu \mathrm{g} \mathrm{A} \beta_{1-42} \\
\text { i.c.v. }\end{array}$} & $\downarrow$ escape latency MWM & & \multirow[t]{2}{*}{ Memory-improving effect } \\
\hline & & & & $\uparrow$ step-through latency PAP & & \\
\hline & & & & \multirow{2}{*}{$\begin{array}{l}\downarrow \text { cortical and hippocampal } \\
\mathrm{A} \beta_{1-40} \text { and } A \beta_{1-42}\end{array}$} & Activation of $\alpha$-secretase & \multirow{2}{*}{$\begin{array}{l}\text { Promotion of the non- } \\
\text { amyloidogenic pathway }\end{array}$} \\
\hline & & & & & Inhibition of $\beta$ - and $\gamma$-secretases & \\
\hline & & & & $\downarrow$ cell death & $\begin{array}{l}\text { Inhibition of MAPK, NF- } \mathrm{KB} \text {, and } \\
\text { ERK }\end{array}$ & Antiapoptotic activity \\
\hline & \multirow{3}{*}{$\begin{array}{l}\text { PS2 mice } \\
11 \text { to } 17 \text { months } \\
n=6\end{array}$} & \multirow{3}{*}{$\begin{array}{l}\text { EGCG } \\
3 \mathrm{mg} / \mathrm{kg} \\
1 \text { week } \\
\text { oral }\end{array}$} & \multirow[t]{3}{*}{-} & \multicolumn{2}{|l|}{$\downarrow$ escape latency MWM } & Memory-improving effect \\
\hline & & & & \multirow{2}{*}{$\downarrow \mathrm{A} \beta_{1-42}$} & Activation of $\alpha$-secretase & \multirow{2}{*}{$\begin{array}{l}\text { Promotion of the non- } \\
\text { amyloidogenic pathway }\end{array}$} \\
\hline & & & & & Inhibition of $\beta$ - and $\gamma$-secretases & \\
\hline \multirow{4}{*}{$\begin{array}{l}\text { Wang, Y. et } \\
\text { al } 2012\end{array}$} & \multirow{4}{*}{$\begin{array}{l}\mathrm{C} 57 \mathrm{BL} / 6 \mathrm{~J} \partial \text { mice } \\
2 \text { months } \\
\mathrm{n}=22\end{array}$} & EGCG & \multirow[t]{4}{*}{-} & \multirow{4}{*}{$\begin{array}{l}\uparrow \text { proliferation } \\
\uparrow \text { neurogenesis } \\
\uparrow \text { learning and memory }\end{array}$} & Increase of hippocampal Ptc and & \multirow[t]{4}{*}{ Promotion of adult neurogenesis } \\
\hline & & $20 \mathrm{mg} / \mathrm{kg}$ & & & Gli1 mRNA levels & \\
\hline & & 60 days & & & $\begin{array}{l}\text { Increased hippocampal Shh, Ptc, } \\
\text { and Gli1 protein levels }\end{array}$ & \\
\hline & & i.p. & & & & \\
\hline
\end{tabular}




\begin{tabular}{|c|c|c|c|c|c|c|}
\hline Authors & Animal model & Treatment & Toxic agent & Results & Mechanisms of action & Conclusions \\
\hline \multirow{8}{*}{$\begin{array}{l}\text { Biasibetti, R. } \\
\text { et al } 2013\end{array}$} & \multirow{8}{*}{$\begin{array}{l}\text { Wistar } \precsim \text { rats } \\
90 \text { days } \\
\mathrm{n}=43\end{array}$} & \multirow{4}{*}{$\begin{array}{l}\text { EGCG } \\
10 \mathrm{mg} / \mathrm{kg} \\
4 \text { weeks } \\
\text { ( } 2 \text { weeks after } \\
\text { STZ) }\end{array}$} & \multirow{8}{*}{$\begin{array}{l}\text { STZ } 3 \text { mg/kg } \\
\text { i.c.v. }\end{array}$} & $\uparrow$ time spent in the target & \multirow[t]{2}{*}{$\downarrow$ acetylcolinesterase activity } & \multirow{2}{*}{$\begin{array}{l}\text { Reduction of the cognitive } \\
\text { deficit }\end{array}$} \\
\hline & & & & $\begin{array}{l}\text { quadrant and number of } \\
\text { platform crossings MWM }\end{array}$ & & \\
\hline & & & & \multirow{3}{*}{\multicolumn{2}{|c|}{$\begin{array}{l}\downarrow \text { hippocampal } \\
\text { S100B } \\
\uparrow \text { CSF S100B }\end{array}$}} & Anti-neuroinflamatory activity \\
\hline & & & & & & \\
\hline & & \multirow[t]{4}{*}{ Gavage } & & & & \\
\hline & & & & $\uparrow$ GPx activity & & Antioxidant activity \\
\hline & & & & $\downarrow$ ROS & & \\
\hline & & & & $\downarrow$ nitrite content & & \\
\hline \multirow{9}{*}{$\begin{array}{l}\text { Lee, Y-J. et } \\
\text { al } 2013\end{array}$} & \multirow{9}{*}{$\begin{array}{l}\text { IcrTacSam:ICR } \widehat{\sigma} \\
\text { mice } \\
\text { 5-weeks } \\
n=40\end{array}$} & \multirow{9}{*}{$\begin{array}{l}\text { EGCG } \\
1.5-3 \\
\text { mg/kg/day } \\
28 \text { days } \\
\text { Orally }\end{array}$} & \multirow{9}{*}{$\begin{array}{l}\text { LPS } 250 \mu \mathrm{g} / \mathrm{kg} / \text { day } \\
\text { i.p. } \\
\text { ( } 7 \text { days, } 21 \text { days } \\
\text { after EGCG) }\end{array}$} & \multirow{3}{*}{$\begin{array}{l}\downarrow \text { escape latency MWM } \\
\uparrow \text { step-through latency PAP }\end{array}$} & $\downarrow$ astrocyte activation & \multirow[t]{3}{*}{ Anti-neuroinflamatory activity } \\
\hline & & & & & Decreased levels of M-CSF, & \\
\hline & & & & & ICAM-1, and IL-16 & \\
\hline & & & & \multicolumn{2}{|l|}{$\downarrow$ iNOS and COX-2 activity } & Anti-neuroinflamatory activity \\
\hline & & & & \multirow{2}{*}{$\begin{array}{l}\downarrow \text { number of cortical and } \\
\text { hippocampal }\end{array}$} & Inhibition of $\beta$ - and $\gamma$-secretases & \multirow{4}{*}{$\begin{array}{l}\text { Promotion of the non- } \\
\text { amyloidogenic pathway }\end{array}$} \\
\hline & & & & & Decreased expression of BACE-1 & \\
\hline & & & & $\mathrm{A} \beta_{1-42}$ plaques & Decreased expression of APP & \\
\hline & & & & $\downarrow \mathrm{A} \beta_{1-42}$ & & \\
\hline & & & & $\downarrow$ caspase-3 expression & & Antiapoptotic activity \\
\hline
\end{tabular}




\begin{tabular}{|c|c|c|c|c|c|c|}
\hline Authors & Animal model & Treatment & Toxic agent & Results & Mechanisms of action & Conclusions \\
\hline \multirow{5}{*}{$\begin{array}{l}\text { Jia, N. et al } \\
2013\end{array}$} & \multirow{5}{*}{$\begin{array}{l}\text { APPswe/PS1 } 1 \Delta 9 \text { 程 } \\
\text { mice } \\
(\mathrm{C} 57 \mathrm{BL} / 6) \\
12 \text { months } \\
\mathrm{n}=24\end{array}$} & \multirow{5}{*}{$\begin{array}{l}\text { EGCG } \\
2 \text { or } 6 \mathrm{mg} / \mathrm{kg} \\
4 \text { weeks } \\
\text { Gavage }\end{array}$} & \multirow[t]{5}{*}{-} & \multirow[t]{2}{*}{$\downarrow$ hippocampal $\mathrm{A} \beta_{1-42}$} & $\downarrow$ phosphorylation of IRS-1 & \multirow{2}{*}{$\begin{array}{l}\text { Attenuation of brain insulin } \\
\text { resistance }\end{array}$} \\
\hline & & & & & $\uparrow \mathrm{pAkt}$ and pGSK3 $\beta$ & \\
\hline & & & & \multirow{3}{*}{$\begin{array}{l}\text { Improved MWM escape } \\
\text { latency } \\
\text { Rescue of spatial memory } \\
\text { deterioration }\end{array}$} & \multirow{3}{*}{$\begin{array}{l}\downarrow \text { hippocampal levels of TNF- } \alpha \\
\text { and pJNK }\end{array}$} & \multirow[t]{3}{*}{ Anti-neuroinflamatory activity } \\
\hline & & & & & & \\
\hline & & & & & & \\
\hline \multirow{6}{*}{$\begin{array}{l}\text { Liu, M. et al } \\
2013\end{array}$} & \multirow{6}{*}{$\begin{array}{l}\mathrm{APP} / \mathrm{PS} 1 \triangle \mathrm{E} 9 \overbrace{}^{\lambda} \&+ \\
\text { mice } \\
9 \text { months } \\
\mathrm{n}=20\end{array}$} & \multirow{6}{*}{$\begin{array}{l}\text { EGCG } \\
2 \mathrm{mg} / \mathrm{kg} / \mathrm{day} \\
4 \text { weeks } \\
\text { Intragastric }\end{array}$} & \multirow[t]{6}{*}{-} & \multirow{4}{*}{$\begin{array}{l}\uparrow \text { latency and } \downarrow \text { frequency } \\
\text { to enter dark compartment } \\
\text { in PAT } \\
\text { Improved performance in } \\
\text { MWM }\end{array}$} & \multirow{4}{*}{$\begin{array}{l}\uparrow \text { increased NGF \& proNGF } \\
\text { Activation of TrKA pathway } \\
\text { Inhibition of p75NT pathway }\end{array}$} & \multirow{4}{*}{$\begin{array}{l}\text { Improvement of spatial learning } \\
\text { and memory deficits }\end{array}$} \\
\hline & & & & & & \\
\hline & & & & & & \\
\hline & & & & & & \\
\hline & & & & $\downarrow$ apoptosis & $\downarrow$ caspase-3 & $\begin{array}{l}\text { Antiapoptotic and } \\
\text { antineurodegenerative activity }\end{array}$ \\
\hline & & & & $\begin{array}{l}\downarrow \mathrm{A} \beta_{1-40} \text { plaque burden } \\
\text { (hippocampus) }\end{array}$ & & $\begin{array}{l}\text { Decreased } A \beta \text { brain } \\
\text { accumulation }\end{array}$ \\
\hline
\end{tabular}




\begin{tabular}{|c|c|c|c|c|c|c|}
\hline Authors & Animal model & Treatment & Toxic agent & Results & Mechanisms of action & Conclusions \\
\hline \multirow[t]{7}{*}{$\begin{array}{l}\text { Walker, J.M. } \\
\text { et al } 2014\end{array}$} & $\begin{array}{l}\text { TgCRND } 8 \lesssim \& q \\
\text { mice }\end{array}$ & $\begin{array}{l}\text { EGCG } 0.2 \\
\mathrm{mg} / \mathrm{mL}\end{array}$ & - & $\begin{array}{l}\text { Improved nest building } \\
\text { behaviour }\end{array}$ & & Improvement in cognition \\
\hline & (C3H/C57BL/6) & 50 mg/kg/day & & $\downarrow$ latency in Barnes maze & & \\
\hline & $\begin{array}{l}2 \text { months } \\
\mathrm{n}=42\end{array}$ & $\begin{array}{l}\text { Orally } \\
\text { (drinking } \\
\text { water) }\end{array}$ & & $\begin{array}{l}\downarrow \text { area under the learning } \\
\text { curve }\end{array}$ & & \\
\hline & & $\mathrm{N}=10$ & & $\begin{array}{l}\downarrow \mathrm{A} \beta \text { in brain and } \\
\text { hippocampus }\end{array}$ & & $\begin{array}{l}\text { Decreased } A \beta \text { brain } \\
\text { accumulation }\end{array}$ \\
\hline & & $\begin{array}{l}\text { + Voluntary } \\
\text { exercise }\end{array}$ & & & & \\
\hline & & $\mathrm{N}=10$ & & & & \\
\hline & & 4 months & & & & \\
\hline
\end{tabular}

$\alpha$-CTF: alpha C-terminal fragment of APP; A : amyloid beta; ADAM10: a desintegrin and metalloprotease domain 10; APP: amyloid precursor protein; Akt: protooncogen c-Akt; BACE-1: beta-site APP-cleaving enzyme 1; c-Abl: c-abl oncogene 1; COX-2: cytochrome C oxidase 2; CSF: Cerebrospinal fluid; ERK: extracellular signal-regulated kinase 2; FE65: APBB1 - amyloid beta (A4) precursor protein-binding, family B, member 1; G6PDH: glucose-6-phosphate dehydrogenase; GPx: gluthatione peroxidase; GR: gluthatione reductase; GSH: gluthatione; GSK-3ß: glycogen synthase kinase 3 beta; ICAM-1: intracellular adhesion molecule 1; i.c.v.: intracerebroventricular; IL-16: interleukin 16; i.p.: intraperitoneal; iNOS: inducible nitric oxide synthase; IRS-1:Insulin receptor substrate 1; JNK: c-Jun N-terminal kinase; LPO: lipid peroxidation; LPS: lipopolysaccharide; MAPK: mitogen activated kinase protein; M-CSF: macrophage colony-stimulating factor; MWM: Morris Water Maze; NF- $\mathrm{kB}$ : nuclear factor of kappa light polypeptide gene enhancer in B-cells; NGF: nerve growth factor; p75NT: nerve growth factor receptor; PAP: passive avoidance performance; PAT: passive avoidance task; PKC: protein kinase C; Ptc: patched; RAWM: radial arm water maze; ROS: reactive oxygen species; S100B: S100 calcium binding protein B; sAPP: soluble amyloid precursor protein; sAPP $\alpha$ : soluble amyloid precursor protein alpha; Shh: Sonic hedgehog; SOD: superoxide dismutase; STZ: streptozotocin; TNF- $\alpha$ : tumor necrosis factor alpha; TrkA: neurotrophic tyrosine kinase, receptor, type 1. 
Table 3b: Summary of the in vivo experiments with Polyphenon 70S and GTC:

\begin{tabular}{|c|c|c|c|c|c|c|}
\hline Authors & Animal model & Treatment & Toxic agent & Results & Pathway & Conclusions \\
\hline \multirow{6}{*}{$\begin{array}{l}\text { Unno, K. et } \\
\text { al } 2004\end{array}$} & \multirow{6}{*}{$\begin{array}{l}\text { SAMP10 } \& \&+\text { mice } \\
1 \text { month } \\
n=22-32\end{array}$} & \multirow{6}{*}{$\begin{array}{l}\text { Polyphenon } \\
70 \mathrm{~S} \\
35 \mathrm{mg} / \text { day/kg } \\
5 \text { or } 11 \text { months } \\
\text { Oral }\end{array}$} & \multirow[t]{6}{*}{-} & \multirow{6}{*}{$\begin{array}{l}\uparrow \text { cerebrum weight } \\
\downarrow \text { oxidative DNA damage (5 } \\
\text { months treatment) } \\
\downarrow \text { learning times in PAT } \\
\uparrow \text { memory function } \\
\uparrow \text { spatial working memory }\end{array}$} & & \multirow{6}{*}{$\begin{array}{l}\text { Improvement of cognitive } \\
\text { function through prevention of } \\
\text { cerebrum atrophy }\end{array}$} \\
\hline & & & & & & \\
\hline & & & & & & \\
\hline & & & & & & \\
\hline & & & & & & \\
\hline & & & & & & \\
\hline \multirow{6}{*}{$\begin{array}{l}\text { Unno, K. et } \\
\text { al } 2007\end{array}$} & \multirow{6}{*}{$\begin{array}{l}\text { SAMP10 ð mice } \\
1 \text { month } \\
n=7-52\end{array}$} & \multirow{2}{*}{$\begin{array}{l}\text { Polyphenon } \\
70 S\end{array}$} & \multirow[t]{6}{*}{-} & \multirow{6}{*}{$\begin{array}{l}\uparrow \text { cerebrum weight (except } \\
\text { after } 14 \text { m treatment) } \\
\downarrow \text { oxidative DNA damage } \\
\uparrow \text { memory function } \\
\uparrow \text { antioxidative activity in } \\
\text { plasma }\end{array}$} & & \multirow[t]{6}{*}{ Delayed senescence } \\
\hline & & & & & & \\
\hline & & \multirow{3}{*}{$\begin{array}{l}35 \mathrm{mg} / \mathrm{day} / \mathrm{kg} \\
1,5,8,11 \text { or } \\
14 \text { months }\end{array}$} & & & & \\
\hline & & & & & & \\
\hline & & & & & & \\
\hline & & Oral & & & & \\
\hline \multirow{5}{*}{$\begin{array}{l}\text { Haque, A.M. } \\
\text { et al } 2008\end{array}$} & \multirow{5}{*}{$\begin{array}{l}\text { Jcl:Wistar } \widehat{\jmath} \text { rats } \\
\text { 5-week old } \\
\text { n=49 }\end{array}$} & \multirow{5}{*}{$\begin{array}{l}\text { Polyphenon E } \\
(0.5 \% \mathrm{w} / \mathrm{v}) \\
26 \text { weeks } \\
\text { Oral }\end{array}$} & \multirow{5}{*}{$\begin{array}{l}\mathrm{A} \beta_{1-40} \text { cerebral } \\
\text { infusion } 0.5 \mu \mathrm{L} / \mathrm{h} \\
\text { (total } 4.9-5.5 \\
\text { nmol) } \\
\text { (at } 25 \text { weeks) }\end{array}$} & $\downarrow$ reference and working & & \multirow[t]{5}{*}{ Antioxidant activity } \\
\hline & & & & memory errors & & \\
\hline & & & & \multirow{3}{*}{\multicolumn{2}{|c|}{$\begin{array}{l}\downarrow \text { hippocampal LPO and } \\
\text { ROS } \\
\downarrow \text { cortical ROS }\end{array}$}} & \\
\hline & & & & & & \\
\hline & & & & & & \\
\hline \multirow{5}{*}{$\begin{array}{l}\text { Li, Q. et al } \\
2009 a\end{array}$} & \multirow{5}{*}{$\begin{array}{l}\mathrm{C} 57 \mathrm{BL} / 6 \mathrm{~J} q \text { mice } \\
14 \text { months } \\
\mathrm{n}=60\end{array}$} & \multirow{2}{*}{\multicolumn{2}{|c|}{$\begin{array}{l}\text { GTC } \\
0.25-0.5-1 \mathrm{~g} / \mathrm{L}\end{array}$}} & \multirow{5}{*}{$\begin{array}{l}\downarrow \text { swimming distance } \\
\text { MWM } \\
\uparrow \text { time spent in the target } \\
\text { quadrant and number of } \\
\text { platform crossings MWM }\end{array}$} & \multirow{2}{*}{$\begin{array}{l}\text { Increased CREB and PKA } \\
\text { phosphorylation }\end{array}$} & \multirow[t]{2}{*}{ Improved long-term memory } \\
\hline & & & & & & \\
\hline & & \multirow{2}{*}{\multicolumn{2}{|c|}{$\begin{array}{l}6 \text { months } \\
\text { (40-80-160 } \\
\text { mg/kg/day) }\end{array}$}} & & \multirow{3}{*}{$\begin{array}{l}\text { Increased BDNF, Bcl-2, PSD95, } \\
\text { and CaMKII }\end{array}$} & \multirow[t]{3}{*}{ Improved neuronal plasticity } \\
\hline & & & & & & \\
\hline & & Oral & & & & \\
\hline
\end{tabular}




\begin{tabular}{|c|c|c|c|c|c|c|}
\hline Authors & Animal model & Treatment & Toxic agent & Results & Pathway & Conclusions \\
\hline \multirow[t]{4}{*}{$\begin{array}{l}\mathrm{Li} \text {, Q. et al } \\
2009 \mathrm{~b}\end{array}$} & \multirow{4}{*}{$\begin{array}{l}\text { SAMP8 } \precsim \text { mice } \\
8 \text { months } \\
n=45\end{array}$} & \multirow{4}{*}{$\begin{array}{l}\text { GTC (Green } \\
\text { Tea Catechins) } \\
0.5-1 \mathrm{~g} / \mathrm{L} \\
6 \text { months } \\
\text { (75-150 } \\
\text { mg/kg/day) } \\
\text { Oral }\end{array}$} & \multirow[t]{4}{*}{-} & \multirow{2}{*}{$\begin{array}{l}\downarrow \text { escape latency MWM } \\
\uparrow \text { time spent in the target } \\
\text { quadrant and number of } \\
\text { platform crossings MWM }\end{array}$} & $\begin{array}{l}\text { Increased PKA/CREB pathway } \\
\text { activities }\end{array}$ & $\begin{array}{l}\text { Improved LTP and long-term } \\
\text { memory formation }\end{array}$ \\
\hline & & & & & $\begin{array}{l}\text { Increase of BDNF, PSD95, and } \\
\text { CaMKII }\end{array}$ & Improved synaptic function \\
\hline & & & & $\downarrow \mathrm{A} \beta_{1-42}$ oligomers & & \\
\hline & & & & & & \\
\hline
\end{tabular}

A $\beta$ : amyloid beta; Bcl-2: B-cell CLL/lymphoma 2; BDNF: brain derived neurotrophic factor; CaMKII: calcium-calmodulin-dependent protein kinase II; CREB: cAMP responsive element binding protein; GTC: Green Tea Catechins; LPO: lipid peroxidation; MWM: Morris Water Maze; PAT: passive avoidance task; PKA: protein kinase, cAMP dependent, catalytic, alpha; PSD95: post-synaptic density protein 95; ROS: reactive oxygen species. 


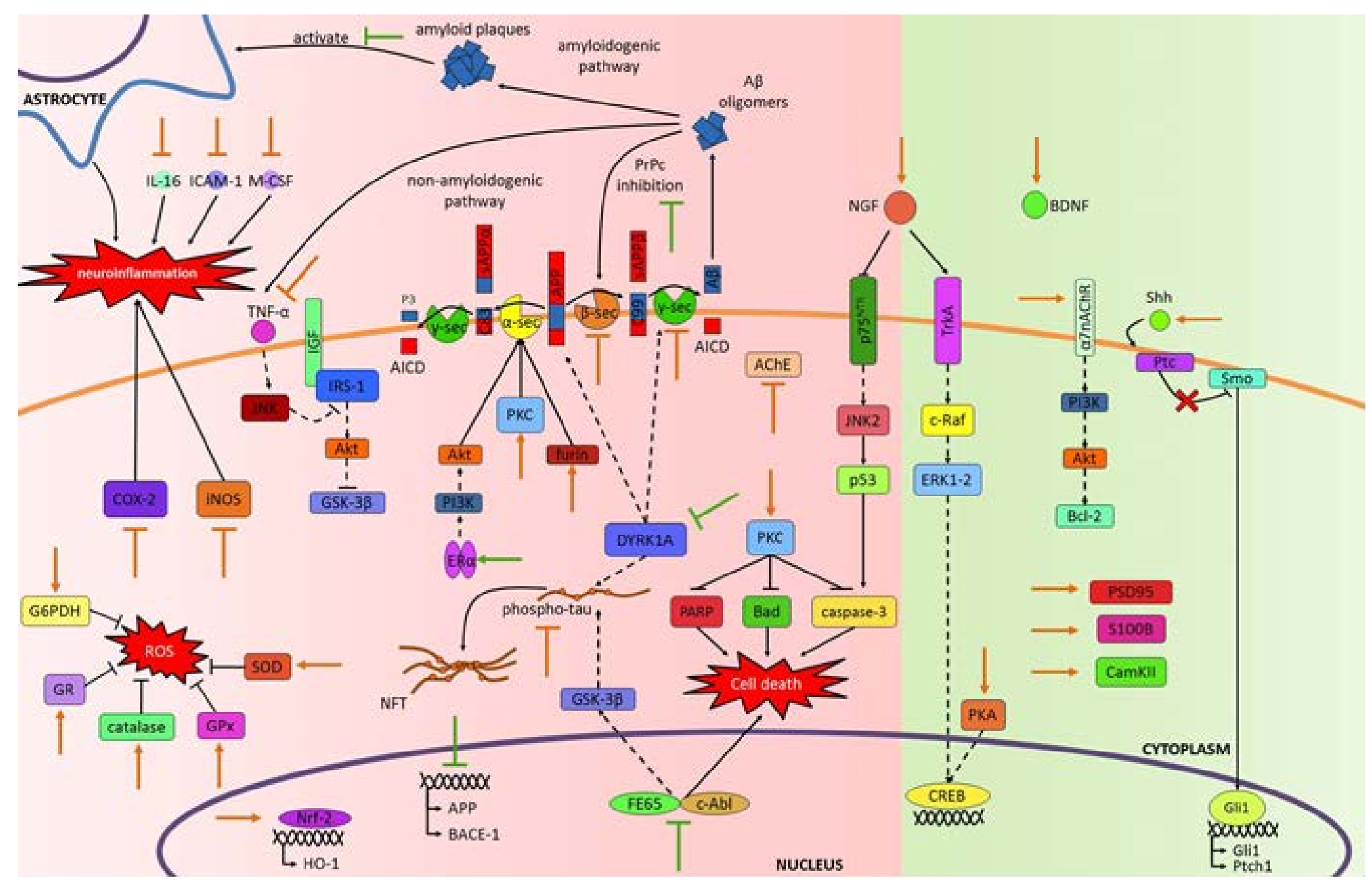

Figure 4 : Schematic representation of EGCG molecular mechanisms. The different pathways involved in the different effects are summarized here: pink background shadows pathways directly related to $\mathrm{AD}$ pathology, and green background the ones that are potentially beneficial by inducing neurorescueing or neuroprotection effects. For each pathway, dashed lines represent phosphorylation, green lines depict direct actions of EGCG, and unknown or indirect effects of EGCG are represented by orange lines (for abbreviations see tables 2, 3a, and 3b). Neuroprotection: the activation of the $\alpha 7 \mathrm{nAChR}$ pathway has been proven to be an effector of EGCG antiapoptotic effects. Neurorescue: the pathways involved in this effect are several and include the inhibition of tau phosphorylation through the inhibition of c-Abl-FE65-dependent activation of GSK-3 $\beta$, the inhibition of several pathways that induce cell death, including p75NTR, while activating the CREB pathway, and other proteins involved in synaptic plasticity; furthermore, EGCG decreases AChE activity. Modulation of APP processing: EGCG acts as an activator of the non-amyloidogenic pathway through different cascades, one of them being its direct interaction with ER $\alpha$; furthermore, it decreases both $\beta$ - and $\gamma$-secretase activities as well as inhibiting APP and BACE-1 expression; finally, it inhibits oligomer formation preventing the inhibition of PrPc (an inhibitor of BACE-1). Effects on tau and DYRK1A: the direct inhibition of DYRK1A has an effect on its kinase activity, preventing the phosphorylation of tau, APP, and PSEN-1, furthermore EGCG inhibits tau phosphorylation through other unstudied pathways. Protection against oxidative stress: EGCG promotes the activation of antioxidant proteins and the transcription of HO-1 through its activation of Nrf2. Protection against neuroinflammation: through the inhibition of amyloid plaque-induced astrocyte activation, as well as the inhibition of some proinflammatory cytokines and proteins, EGCG ameliorates the neuroinflammation present in AD. Promotion of adult neurogenesis: the activation of the Shh pathway by EGCG leads to an increased neurogenesis, on the other hand, EGCG acts sinergically with BDNF to promote neuronal differentiation. 
to an increase in NGF leading to activation of the TrkA pathway, and inhibition of p75 ${ }^{\mathrm{NIR}}$ (Figure 4)[109].

However, the beneficial effects of EGCG on cognition are not limited to aged or transgenic mice, as the administration of $20 \mathrm{mg} / \mathrm{kg}$ EGCG daily for 2 months in 2month-old mice improved both object recognition and spatial memory [110]. Beneficial effects could also be detected in a non-transgenic mouse model (icv-STZ mouse) of AD. STZ leads to a chronic brain dysfunction caused by increased oxidative stress, and is characterized by progressive long term deficits in learning, memory, and cognition that were rescued upon EGCG administration in young rats two weeks. This cognitive effect could be related to the inhibitory effect of EGCG on the AChE activity, which is increased after STZ administration [111]. Regarding the molecular mechanisms EGCG [103] decreases caspase-3 brain levels, suggesting an antiapoptotic activity [109, 112]. Additionally, EGCG decreases S100B hippocampal levels triggered by STZ i.c.v. administration, while increasing its levels in CSF (Figure 4) [111]. S100B has a dose dependent effect on neurons, protecting them from apoptosis, stimulating neurite outgrowth, and long-term neuronal plasticity at nanomolar concentrations, and increasing $A \beta$ toxicity and apoptosis at micromolar concentrations [113]. EGCG neurorescueing capacity is interesting in clinical practice because it opens the possibility of using it as treatment when $\mathrm{AD}$ is already diagnosed to stop its advance, ideally at the first stages of the disease. Its ability to arrest apoptosis would lead to a decreased neuronal loss and, thus, possibly, to amelioration of the memory problems. Additionally, EGCG can prevent oxidative damage in vivo, as shown with the STZ model, covering yet another of the main causes of the disease.

\subsubsection{Modulation of APP processing}

EGCG has shown its capacity to regulate APP processing in several experiments that would reduce $A \beta$ deposition. One of the first experiments to prove that EGCG was able to promote the activation of the non-amyloidogenic pathway was performed in SH-SY5Y (human neuroblastoma cell line) and PC12 cell lines, known to constitutively express APP and release sAPP $\alpha$ into the culture medium. EGCG treatment increased the amount of sAPP $\alpha$ released in a dose-dependent manner. This augmented liberation was subject to a stimulation of PKC activity leading to an increase in the $\alpha$-secretase activity (Figure 4) [94]. In a similar experiment, Rezai-Zadeh et al tested the effect of EGCG in SweAPPN2a cell line - murine N2a cells transfected with human Swedish mutant form of APPobtaining the same results regarding the $\operatorname{sAPP} \alpha$ release. Additionally, the intracellular amounts of $\alpha$-CTF were also increased, as was the $\alpha$-secretase activity. $\mathrm{A} \beta$ concentrations were analyzed both in SweAPPN2a cell line and in primary neurons obtained from Tg2576, EGCG treatment decreased both $\mathrm{A} \beta_{1-40}$ and $\mathrm{A} \beta_{1-42}[114]$.

Comparable results were obtained in a supplementary experiment using $\mathrm{SH}-\mathrm{SY} 5 \mathrm{Y}$ cell line and $\mathrm{CHO} / \Delta \mathrm{NL}$ (Chinese Hamster ovary cells transfected with human
APP695 containing the Swedish mutation). Moreover, the treatment with EGCG decreased the levels of holo-APP and total APP. This reduction is due to EGCG iron chelating properties that lead to the inhibition of APP translation [115]. Further experimentation proved that ADAM10 was the $\alpha$-secretase involved in EGCG anti-amyloidogenic activity. EGCG increases ADAM10 maturation, being, thus, a key process for the changes in the concentrations of APP cleavage products (Figure 4) [116]. Additional experiments by Lin et al kept in line with the previous observations, namely that EGCG increased $\mathrm{sAPP} \alpha$ release [95].

The mechanism that leads to the induction of the maturation of ADAM10 by EGCG seems to be dependent on $\mathrm{ER} \alpha$ (estrogen receptor alpha) binding. ER $\alpha$ induces the PI3K/Akt pathway increasing the maturation of ADAM10. However, EGCG can act through furin increasing its levels and, because furin is a convertase that takes part in the maturation of ADAM10, the levels of mature ADAM10 are increased (Figure 4) [117]. However, not all the effects of EGCG on APP processing are dependent on the activation of the non-amyloidogenic pathway or the decrease of APP translation. Shimmyo et al reported the capacity of EGCG to suppress BACE-1 activation when it was co-incubated with $\mathrm{A} \beta_{1-42}$ (Figure 4). Therefore, this would mean that EGCG is also able to suppress the amyloidogenic pathway [118]. This action could be related to the fact that EGCG has proven to be able to affect the oligomer conformation, preventing the $\mathrm{A} \beta$ oligomers from binding PrPc avoiding, therefore, $\mathrm{A} \beta$ inhibition of the PrPc inhibition of BACE-1 activity, stopping $A \beta$ induced cell death (Figure 4) [119].

Following the results obtained in the cell model, Levites et al, used young adult mice administered with 2 $\mathrm{mg} / \mathrm{kg}$ EGCG and analyzed the amounts of both APP and sAPP. EGCG administration in these non-AD mice model proved to decrease membrane bound APP in the hippocampus when administered orally for at least 7 days, and to increase sAPP in the hippocampus after 14 days of administration. Furthermore, and in accordance to the results from cell culture, both PKC $\alpha$ and PKC $\varepsilon$ translocated to the membrane and increased in the cytosolic fraction. This would lead to an increased PKC-dependent activation of the $\alpha$-secretase promoting the non-amyloidogenic pathway (Figure 4) [94].

The effect of EGCG on the activation of $\alpha$-secretase was confirmed in vivo using aged Tg2576 mice receiving EGCG either i.p. or i.c.v. Both increased $\alpha$-CTF and sAPP $\alpha$ brain levels while decreasing $A \beta_{1-40}$ and $A \beta_{1-42}$. These results are coupled with an increased $\alpha$-secretase activity [114]. A subsequent experiment with chronic oral administration (6 months) of EGCG, provided consistent results regarding the decrease in $A \beta_{1-40}$ and $A \beta_{1-42}$, both soluble and insoluble forms, and the increase in sAPP $\alpha$ release. Additionally, A $\beta$ deposition was decreased in several brain areas, including the hippocampus, and ADAM10 maturation was increased. Therefore, the beneficial cognitive effects detected upon i.p. EGCG administration could derive from this shift in the APP processing pathways that lead to a decreased plaque burden 
[105]. Lin et al obtained similar results, regarding hippocampal $A \beta_{1-40}$ and $A \beta_{1-42}$ levels, and $A \beta$ plaque load in the Tg2576 with a lower EGCG dose (20 mg/kg/day) [95]. This decrease of $A \beta_{1-40}$ and $A \beta_{1-42}$ levels has been consistently seen in several other experiments using either induced or aging models of $\mathrm{AD}$, as well as pure EGCG or green tea catechins [100, 101, 107, 112]. Additionally, Lee et al observed a decreased number of amyloid plaques when mice were pretreated with EGCG before LPS injection [112]. Some in vivo studies reported decreases in the activities of $\beta$ - and $\gamma$-secretases, $[100,101]$ as well as in the expression of BACE-1 and APP [112], hinting to a possible promotion of the non amyloidogenic pathway through inhibition of the amyloidogenic, in accordance with the results obtained by Shimmyo et al in cell culture (Figure 4) [118]. Additionally, as seen in the introduction, $A \beta$ is known to trigger brain insulin resistance. A recent study using the double transgenic mouse model APPswe/PS1 $\Delta \mathrm{E} 9$, explored the effect of EGCG on brain insulin resistance. EGCG could decrease the phosphorylation of S636 in IRS-1, while increasing its downstream targets pAkt and pGSK3- $\beta$ (Figure 4) [108]. Therefore, EGCG decreases brain insulin resistance. It is possible that this effect is mediated, in part, through the reduction $\mathrm{A} \beta_{1-42}$ hippocampal levels. Additionally, EGCG did also decrease the levels of TNF- $\alpha$ and pJNK, markers of neuroinflammation (Figure 4) [108].

In summary, the effects of EGCG on APP processing have been studied extensively because of APP relation with AD. EGCG acts on $A \beta$ production through two different pathways, on one hand it decreases $A \beta$ production by activating ADAM10, favoring the non-amyloidogenic pathway, and on the other hand reduces the amyloidogenic pathway through the inhibition of BACE-1. Less $A \beta$ production would lead to a decreased formation of toxic $A \beta$ oligomers and plaques. Oligomers are one of the causes of synaptic loss and neurodegeneration, while the plaques take part in the inflammatory process. Additionally, decreased concentrations of $A \beta$ would also have an impact on LPO production. Finally, sAPP $\alpha$ is a known neuroprotective factor and stimulator of the adult neurogenesis, and increased concentrations should lead to beneficial effects. Therefore, EGCG effects on APP processing would have consequences on other AD pathways. However, it is worth noting that, as with most of the mechanisms listed, the treatment would need to start before the disease begins, because the accumulation of $A \beta$ in the synapses is a long-term process that should be stopped from the start as to avoid the onset of the disease.

\subsubsection{Effects on tau and DYRK1A}

Rezai-Zadeh et al observed a decrease in the sarkosylsoluble phospho-tau upon EGCG treatment in the Tg2576 model (Figure 4) [105], which is interesting since sarkosyl soluble phospho-tau are probably the neurotoxic forms of phospho-tau. However, this is the only study so far to research this effect, since tau aggregation correlates with the degree of cognitive impairment, its decrease could be relevant to the treatment of $\mathrm{AD}$.
Among other genes of interest, DYRK1A has been associated with $\mathrm{AD}$ both in general population and in $\mathrm{DS}$ patients [49, 50, 52], EGCG effects on this protein should be taken into consideration. EGCG is known to inhibit DYRK1A activity in vitro,(Figure 4) [120] and an in vivo study using Dyrk1a transgenic mice overexpressing this gene proved that the administration of a green tea extract from gestation was able to rescue brain morphogenesis alterations, learning deficits and several markers of synaptic plasticity [121]. Therefore it is possible that EGCG could modify DYRK1A activity on APP, tau, and PSEN-1 having yet another mechanism to prevent the course of AD. However, no experimentation has been done in this regard and it remains a hypothesis.

\subsubsection{Protection against oxidative stress}

Both the neuroprotection and the neurorescueing capacities of EGCG are related to several intra and extracellular mechanisms that, ultimately, lead to a decrease in the neurotoxicity triggered by $\mathrm{A} \beta$. Lin et al, and He et al highlight an EGCG mediated decrease in A $\beta$-dependent ROS production in their experiments [95, 97]. Co-incubating EGCG at various concentrations, and $5 \mu \mathrm{M} \mathrm{A} \beta_{1-42}$ for 48 hours also attenuated ROS production in a primary culture from rat cerebral cortex [118]. Thereby, EGCG reduces the oxidative stress caused by $A \beta$ in cell culture. Furthermore, pre-incubating rat hippocampal neurons (H 19-7) with 25 $\mu \mathrm{M}$ EGCG for 12 hours before exposing them to $50 \mathrm{mU} / \mathrm{mL}$ GOX (glucose oxidase), maintained cell viability due to the induction of HO-1 (heme oxygenase) expression through Nrf2 (nuclear factor, erythroid-2) (Figure 4) [122]. The modulation of the Nrf2/ARE pathway by food polyphenols, and in particular by EGCG, is a nutritional neuroprotective strategy for cognitive and neurodegenerative disorders that should be taken into consideration when claiming the antioxidant effects of such compounds [123]. As highlighted in the introduction, oxidative stress, besides being toxic on its own, triggers several other mechanisms involved in the disease. Therefore lowering the ROS concentrations should have an impact on the other areas of the disease, even if it is not sufficient to stop it completely. In addition, the ability of EGCG to induce Nrf2-dependent gene expression has also been seen in cell models of cancer, where Nrf2 activation was dependent on several phosphorylation cascades (Figure 4) $[124,125]$. Furthermore, Nrf2 seems to both regulate and be regulated by miRNA, which are implicated in the regulation of phase II detoxifying enzymes and pro-oxidative enzymes [126]. Although the modulating effects of EGCG on miRNA have mainly been studied in cancer $[127,128]$, it could still be possible that part of the antioxidant effects of EGCG on AD were related to this mechanism.

The modulation of ROS production by EGCG has been studied in several animal models. Haque et al reported a decrease in hippocampal and cortical ROS production, as well as in hippocampal LPO in their AD induced mouse model, after Polyphenon E pre-administration [99]. Similarly, the administration of EGCG in the STZ induced AD model reduced ROS content while upregulating the antioxidant enzyme GPx [111]. In addition, previous studies 
in aged rats had already reported the ability of oral EGCG to upregulate the activity of several antioxidant enzymes including GPx, SOD, catalase, GR, and G6PDH, as well as antioxidant molecules such as ascorbic acid, $\alpha$-tocopherol, and GSH (Figure 4). Furthermore, EGCG could also decrease other markers of oxidation, such as LPO or the amount of protein carbonyls [129].

Studies using SAMP10 mice treated with Polyphenon $70 \mathrm{~S}$ for different time periods reported changes in brain anatomy. The treatment was able to prevent the decrease in brain weight observed in these mice, as well as the increased oxidative DNA damage $[130,131]$. This prevention of the brain atrophy correlated with the cognitive improvements observed, especially with the learning improvements [130]. Additionally, Polyphenon 70S treatment increased the antioxidant activity in serum in aged mice compared to the age-matched controls [131].

In summary, EGCG has proven to lower oxidative stress both in vivo and in vitro. This effect is achieved by a dual mechanism, reducing ROS production at the same time that it increases the natural antioxidant defenses. One of the most important findings is that EGCG is able to produce its antioxidant effect in aged models that have, already, an increased oxidative stress.

\subsubsection{Protection against neuroinflammation}

As stated in the introduction, oxidative stress and neuroinflammation are closely related. Chronic neuroinflammation is predominant in $\mathrm{AD}$ brains, and is not an isolated sign, but rather a product of the combined action of oxidative stress, $\mathrm{A} \beta$ plaques, and others. Furthermore, inflammation increases $A \beta$ concentrations in the brain, and several cytokines induce $\mathrm{A} \beta$ plaques aggregation. Neuroinflammation is also a cause for oxidative stress through feedback mechanisms, and thus, a decrease in neuroinflammation would affect oxidative stress as well as $\mathrm{A} \beta$ deposition.

In a set of experiments performed by the same research group, EGCG demonstrated antineuroinflammatory properties against LPS (lipopolysaccharide) induced neuroinflammation. On their first experiment, LPS was injected i.c.v. after a 3-week pretreatment with EGCG; the pretreatment prevented the increase in GFAP positive cells as well as the induction of iNOS and COX-2, as well as the deficits in PAP and MWM (Figure 4) [101]. Recently, they have replicated such results in an in vitro model using astrocytes from newborn rats. In this experiment EGCG reduced the LPS-induced activation of iNOS and COX2 as well as the concentrations of several cytokines [112]. Furthermore, they used the scheme of the previous in vivo experiment to induce systemic inflammation and evaluate the effects of EGCG on neuroinflammation in that model.. The results for this new experiment were comparable with the previous including: prevention of the astrocyte activation as well as of the increased levels of MCSF, ICAM-1, IL-16, and of the increased activities of iNOS and COX-2 (Figure 4). This study is able to connect the effects seen in the biochemical analysis with the improvements in behavior [112]. These results are in agreement with the in vitro experiments, concerning neuroprotective activities of EGCG.

\subsubsection{Promotion of adult neurogenesis}

Another possible beneficial effect of an $\mathrm{AD}$ drug would be its neurogenesis-promoting effects. EGCG was also shown to be able to promote differentiation in PC12 cells, and thus it could induce the regeneration of injured cells in the damaged areas of the brain, such as the hippocampus [103]. Moreover, culturing mouse NPCs with different concentrations of EGCG promoted NPCs proliferation through the Shh pathway activation (Figure 4). However, in this case, EGGC did not exert an effect on differentiation [110]. These effects on differentiation and proliferation could be related to the increase of $\operatorname{sAPP} \alpha$ concentrations, because this peptide is a known inducer of neurogenesis.

Following these results that demonstrated the effect of EGCG on NPCs proliferation in vitro, Wang et al, performed in vivo experiments using C57BL/6J mice receiving 20 $\mathrm{mg} / \mathrm{kg}$ EGCG daily for 60 days. These in vivo experiments proved that EGCG could induce adult hippocampal neurogenesis in vivo thanks to the activation of Shh pathway. This enhanced adult neurogenesis was coupled to an improvement in the cognitive performance [110]. Related to this, although through a different mechanism, EGCG and green tea polyphenols have proven to have the power to potentiate the neuritogenesis produced by low doses of BDNF, achieving the neuritogenic power of high doses of BDNF (Figure 4) [132]. As stated in the introduction, the potentiation of the neurogenesis could be a potential therapeutic approach in regards to improve the plasticity. Therefore, the effects on neurogenesis exerted by EGCG would be of interest, because in AD there seems to be a decrease in the number of NPCs. However, research in this aspect is still very preliminary, and more experiments are needed to confirm both the state of adult neurogenesis in $\mathrm{AD}$ and the effect of EGCG on it.

\section{CLINICAL TRIALS}

A total number of 84 registered clinical trials (61 closed studies and 23 ongoing) aim to study the potential use of EGCG in humans. Some of these trials are evaluating its effect in $\mathrm{AD}$ as well as in other neurodegenerative diseases such as multiple sclerosis, Huntington disease, amyloidosis or Parkinson disease, for these diseases there are only results available for two clinical trials, and none of them examined changes in cognitive function or neurological status [133, 134]. Park et al studied the effects of a combination of green tea extract and L-theanine on memory and attention in 91 subjects with mild cognitive impairment; the results show an improvement in cognitive function [135]. Besides, there are two ongoing clinical trials using a green tea extract in the prevention of $\mathrm{AD}$ both in $\mathrm{DS}$ and in the general population: (i) Sunphenon EGCG in the Early Stage of AD (SUN-AK) (NCT00951834) and (ii) Normalization of DYRK1A and 
APP Function as an Approach to Improve Cognitive Performance and Decelerate AD Progression in DS Subjects: Epigallocatechin Gallate as Therapeutic Tool (NCT01699711). As soon as the ongoing clinical trials evaluate the results, more information about the role that EGCG neuroprotective effects play in the management of neurodegenerative diseases will be available.

\section{CONCLUDING REMARKS}

The current evidence of EGCG in the context of AD management has been reviewed here. This compound is extensively present in diet regimes that have been related to beneficial health effects (i.e. Japanese) and is contained in foods that are consumed daily (e.g. green tea), suggesting that its regular consumption, even leading to small amounts in plasma, could exert protective biological effects. A factor associated to its dietary origin is its safety in humans as a wide range of doses has been tested in the area of chemoprevention without major adverse effects observed [136]. Its biological effects are broad (Figure 5), conferring neuroprotection to different $\mathrm{AD}$ insults and being even able to rescue the detrimental effects exerted by such insults. A wide range of identified underlying mechanisms demonstrates that EGCG is not only antioxidant by both decreasing ROS production and increasing the levels of antioxidant enzymes through the activation of Nrf2-pathway. as a therapeutic agent. Neuroinflammation, which together with oxidative stress has been seen to be important in AD brains, can also be reduced by EGCG, mainly through the inhibition of pro-inflammatory enzymes and the decrease in the production of cytokines, due to a reduction of the gliosis. Coupled to this anti-inflammatory effect, this compound can act on the insulin signaling, another pathway that is affected in $\mathrm{AD}$, even if it is not exclusive of it. Both $\mathrm{AD}$ and diabetes share this alteration in brain insulin signaling that accounts for part of the deficits seen in AD. All these effects highlight the multiple applications that EGCG has in the field of neurodegeneration. However, it has some interesting effects that specifically target some of the most key causes of AD such as APP and tau hyper phosphorylation. Additionally, EGCG has also proven to decrease apoptosis and to promote both differentiation and adult neurogenesis, this would lead to a reduction in the decrease of cells observed in $\mathrm{AD}$ and to an increase in the synaptic plasticity. All these effects translate in an improvement of cognitive performance leading in animal models. Nevertheless, all these results need to be confirmed in humans to consider EGCG as an effective treatment for $\mathrm{AD}$.

Furthermore, more research is needed to refine the mechanisms affected by EGCG. The kinase DYRK1A, which would explain the use not only in AD but also for DS, or the effect of EGCG on the miRNAs will certainly be extremely interesting targets in the future.

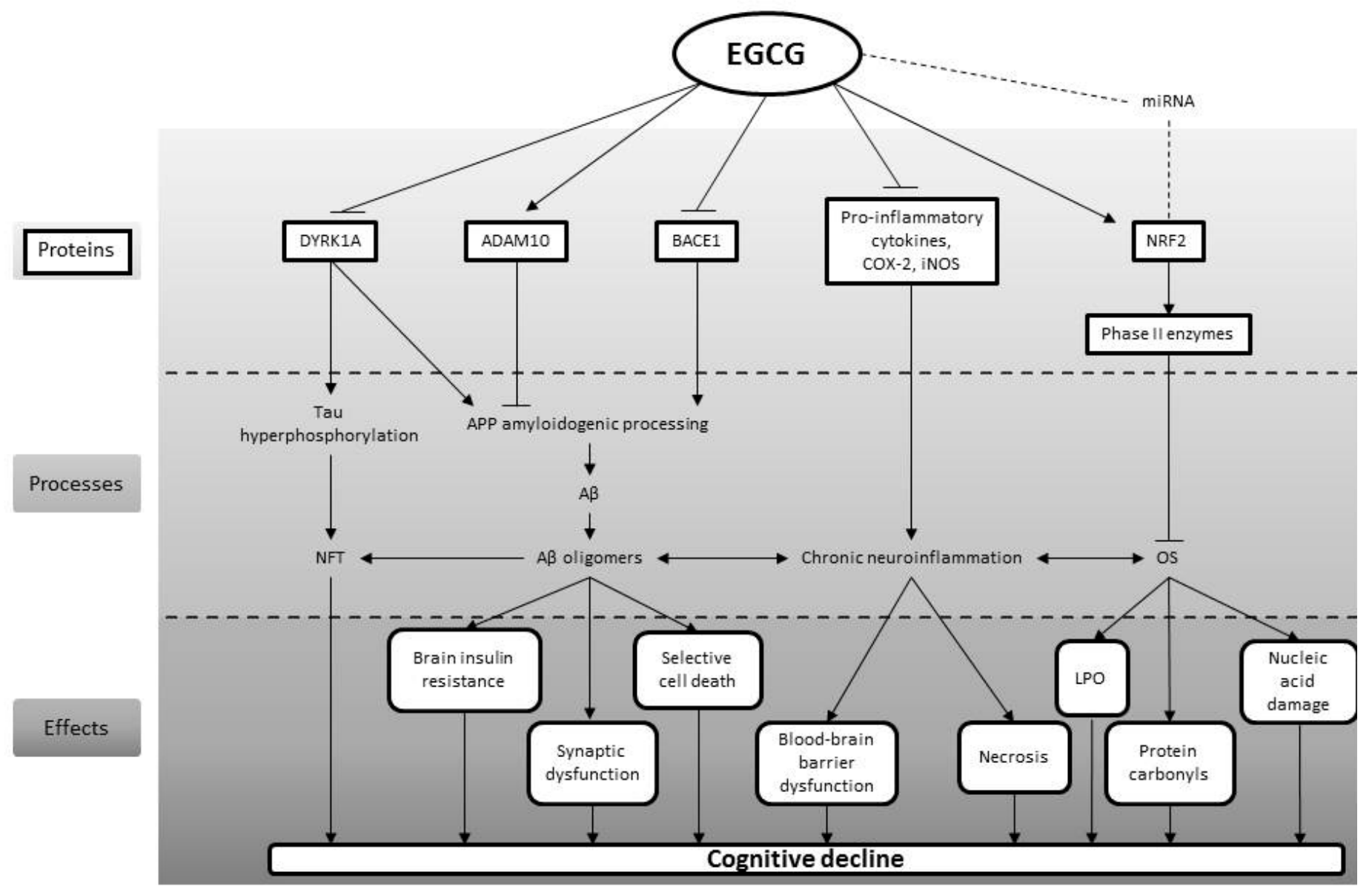

Figure 5: Schematic representation of EGCG mechanism of action. 


\section{CONFLICT OF INTEREST}

The authors report no conflict of interest. This work was supported by grants, donations and agreements from Fondation Jérôme Lejeune (Paris, France), Instituto de Salud Carlos III FEDER, (PI11/00744), MINECO (SAF201019434, MTM2012-38067-C02-01 and SAF2013-49129-C1R), EU (Era Net Neuron PCIN-2013-060) co-financed by European Regional Development Fund, DIUE de la Generalitat de Catalunya (SGR 2009/1450, SGR 2014/464 SGR 2014/1125). We acknowledge support of the Spanish Ministry of Economy and Competitiveness, 'Centro de Excelencia Severo Ochoa 2013-2017’, SEV-2012-0208.Jose Rodríguez-Morató was supported by a FI-DGR 2013 predoctoral fellowship from the Generalitat de Catalunya.

\section{ACKNOWLEDGEMENTS}

Laura Xicota and Jose Rodríguez-Morató contributed equally to the manuscript. Mara Dierssen and Rafael de la Torre directed the work, and corrected and discussed the manuscript. 


\section{REFERENCES}

[1] Lin, M.T.; Beal, M.F., Mitochondrial dysfunction and oxidative stress in neurodegenerative diseases. Nature, 2006, 443, (7113), 787-795.

[2] Lagouge, M.; Larsson, N.G., The role of mitochondrial DNA mutations and free radicals in disease and ageing. Journal of Internal Medicine, 2013, 273, (6), 529-543.

[3] Harman, D., Aging: A Theory Based on Free Radical and Radiation Chemistry. Journal of Gerontology, 1956, 11, (3), 298-300.

[4] Harman, D., Origin and evolution of the free radical theory of aging: a brief personal history, 1954-2009. Biogerontology, 2009, 10, (6), 773-781.

[5] Halliwell, B., Free radicals and antioxidants: updating a personal view. Nutrition Reviews, 2012, 70, (5), 257-265.

[6] Atwood, C.S.; Obrenovich, M.E.; Liu, T., et al., Amyloid- $\beta$ : a chameleon walking in two worlds: a review of the trophic and toxic properties of amyloid- $\beta$. Brain Research Reviews, 2003, 43, (1), 1-16.

[7] Hensley, K.; Hall, N.; Subramaniam, R., et al., Brain Regional Correspondence Between Alzheimer's Disease Histopathology and Biomarkers of Protein Oxidation. Journal of Neurochemistry, 1995, 65, (5), 2146-2156.

[8] Barnham, K.J.; Masters, C.L.; Bush, A.I., Neurodegenerative diseases and oxidative stress. Nat Rev Drug Discov, 2004, 3, (3), 205-214.

[9] Halliwell, B., Oxidative stress and neurodegeneration: where are we now? Journal of Neurochemistry, 2006, 97, (6), 1634-1658.

[10] Halliwell, B., Free Radicals and Antioxidants: A Personal View. Nutrition Reviews, 1994, 52, (8), 253-265.

[11] Böhm, F.; Edge, R.; McGarvey, D.J.; Truscott, T.G., $\beta$-Carotene with vitamins $E$ and $C$ offers synergistic cell protection against NOx. FEBS Letters, 1998, 436, (3), 387-389.

[12] Auten, R.L.; Davis, J.M., Oxygen toxicity and reactive oxygen species: the devil is in the details. Pediatr Res, 2009, 66, (2), 121-127.

[13] Klann, E., Cell-Permeable Scavengers of Superoxide Prevent Long-Term Potentiation in Hippocampal Area CA1. Journal of Neurophysiology, 1998, 80, (1), 452457.

[14] Gahtan, E.; Auerbach, J.M.; Groner, Y.; Segal, M., Reversible impairment of long-term potentiation in transgenic $\mathrm{Cu} / \mathrm{Zn}-\mathrm{SOD}$ mice. European Journal of Neuroscience, 1998, 10, (2), 538-544.

[15] Serrano, F.; Klann, E., Reactive oxygen species and synaptic plasticity in the aging hippocampus. Ageing Res Rev, 2004, 3, (4), 431-443.

[16] Jack, C.R., Jr., Alzheimer disease: new concepts on its neurobiology and the clinical role imaging will play. Radiology, 2012, 263, (2), 344-361.
[17] Valls-Pedret, C.; Lamuela-Raventós, R.M.; MedinaRemón, A., et al., Polyphenol-rich foods in the Mediterranean diet are associated with better cognitive function in elderly subjects at high cardiovascular risk. $J$ Alzheimers Dis, 2012, 29, (4), 773-782.

[18] Goedert, M.; Spillantini, M.G., A century of Alzheimer's disease. Science, 2006, 314, (5800), 777-781.

[19] World Alzheimer Report 2009. http://www.alz.co.uk/research/files/WorldAlzheimerReport.p df (June 2015),

[20] Wortmann, M., Dementia: a global health priority highlights from an ADI and World Health Organization report. Alzheimers Res Ther, 2012, 4, (5), 40.

[21] Alzheimer, A., Über eine eigenartige Erkankung der Hirnrinde. All. Z. Psychiatr., 1907, 64, 146-148.

[22] Alzheimer, A.; Stelzmann, R.A.; Schnitzlein, H.N.; Murtagh, F.R., An English translation of Alzheimer's 1907 paper, "Uber eine eigenartige Erkankung der Hirnrinde". Clin Anat, 1995, 8, (6), 429-431.

[23] Bertram, L.; Tanzi, R.E., Thirty years of Alzheimer's disease genetics: the implications of systematic meta-analyses. Nat Rev Neurosci, 2008, 9, (10), 768-778.

[24] Piaceri, I.; Rinnoci, V.; Bagnoli, S.; Failli, Y.; Sorbi, S., Mitochondria and Alzheimer's disease. Journal of the Neurological Sciences, 2012, 322, (1-2), 31-34.

[25] Verghese, P.B.; Castellano, J.M.; Holtzman, D.M., Apolipoprotein $\mathrm{E}$ in Alzheimer's disease and other neurological disorders. Lancet Neurol, 2011, 10, (3), 241252.

[26] Fuster-Matanzo, A.; Llorens-Martin, M.; Hernandez, F.; Avila, J., Role of neuroinflammation in adult neurogenesis and Alzheimer disease: therapeutic approaches. Mediators Inflamm, 2013, 2013, 260925.

[27] Niranjan, R., Molecular Basis of Etiological Implications in Alzheimer's Disease: Focus on Neuroinflammation. Mol Neurobiol, 2013.

[28] Craig, L.A.; Hong, N.S.; McDonald, R.J., Revisiting the cholinergic hypothesis in the development of Alzheimer's disease. Neurosci Biobehav Rev, 2011, 35, (6), 1397-1409.

[29] Bartus, R.T.; Dean, R.L., 3rd; Beer, B.; Lippa, A.S., The cholinergic hypothesis of geriatric memory dysfunction. Science, 1982, 217, (4558), 408-414.

[30] Coyle, J.T.; Price, D.L.; DeLong, M.R., Alzheimer's disease: a disorder of cortical cholinergic innervation. Science, 1983, 219, (4589), 1184-1190.

[31] Kessels, H.W.; Nabavi, S.; Malinow, R., Metabotropic NMDA receptor function is required for betaamyloid-induced synaptic depression. Proc Natl Acad Sci $U$ $S$ A, 2013, 110, (10), 4033-4038.

[32] Ferreira, S.T.; Vieira, M.N.; De Felice, F.G., Soluble protein oligomers as emerging toxins in Alzheimer's 
and other amyloid diseases. IUBMB Life, 2007, 59, (4-5), 332-345.

[33] Nalivaeva, N.N.; Turner, A.J., The amyloid precursor protein: A biochemical enigma in brain development, function and disease. FEBS Lett, 2013, 587, (13), 2046-2054.

[34] Haass, C.; Kaether, C.; Thinakaran, G.; Sisodia, S., Trafficking and proteolytic processing of APP. Cold Spring Harb Perspect Med, 2012, 2, (5), a006270.

[35] Postina, R., Activation of $\alpha$-secretase cleavage. $J$ Neurochem, 2011.

[36] Mu, Y.; Gage, F.H., Adult hippocampal neurogenesis and its role in Alzheimer's disease. Mol Neurodegener, 2011, 6, 85.

[37] Webb, R.L.; Murphy, M.P., \&\#x03B2;-Secretases, Alzheimer's Disease, and Down Syndrome. Current Gerontology and Geriatrics Research, 2012, 2012, 8.

[38] Acquati, F.; Accarino, M.; Nucci, C., et al., The gene encoding DRAP (BACE2), a glycosylated transmembrane protein of the aspartic protease family, maps to the Down critical region. FEBS Letters, 2000, 468, (1), 59-64.

[39] Azkona, G.; Amador-Arjona, A.; Obradors-Tarragó, C., et al., Characterization of a mouse model overexpressing beta-site APP-cleaving enzyme 2 reveals a new role for BACE2. Genes, Brain and Behavior, 2010, 9, (2), 160-172.

[40] Shi, X.P.; Tugusheva, K.; Bruce, J.E., et al., Betasecretase cleavage at amino acid residue 34 in the amyloid beta peptide is dependent upon gamma-secretase activity. $J$ Biol Chem, 2003, 278, (23), 21286-21294.

[41] Azkona, G.; Levannon, D.; Groner, Y.; Dierssen, M., In vivo effects of APP are not exacerbated by BACE2 co-overexpression: behavioural characterization of a double transgenic mouse model. Amino Acids, 2010, 39, (5), 15711580 .

[42] Sun, X.; He, G.; Song, W., BACE2, as a novel APP $\theta$-secretase, is not responsible for the pathogenesis of Alzheimer's disease in Down syndrome. The FASEB Journal, 2006, 20, (9), 1369-1376.

[43] Cavallucci, V.; D'Amelio, M.; Cecconi, F., Abeta toxicity in Alzheimer's disease. Mol Neurobiol, 2012, 45, (2), 366-378.

[44] De Felice, F.G., Alzheimer's disease and insulin resistance: translating basic science into clinical applications. J Clin Invest, 2013, 123, (2), 531-539.

[45] de la Torre, R.; Dierssen, M., Therapeutic approaches in the improvement of cognitive performance in Down syndrome: past, present, and future. Prog Brain Res, 2012, 197, 1-14.

[46] Dierssen, M., Down syndrome: the brain in trisomic mode. Nat Rev Neurosci, 2012, 13, (12), 844-858.

[47] Rafii, M.S., The pulse of drug development for Alzheimer's disease. Rev Recent Clin Trials, 2010, 5, (1), 5762.
[48] Cheon, M.S.; Dierssen, M.; Kim, S.H.; Lubec, G., Protein expression of BACE1, BACE2 and APP in Down syndrome brains. Amino Acids, 2008, 35, (2), 339-343.

[49] Ferrer, I.; Barrachina, M.; Puig, B., et al., Constitutive Dyrk1A is abnormally expressed in Alzheimer disease, Down syndrome, Pick disease, and related transgenic models. Neurobiol Dis, 2005, 20, (2), 392-400.

[50] Ryoo, S.R.; Cho, H.J.; Lee, H.W., et al., Dualspecificity tyrosine(Y)-phosphorylation regulated kinase 1Amediated phosphorylation of amyloid precursor protein: evidence for a functional link between Down syndrome and Alzheimer's disease. J Neurochem, 2008, 104, (5), 13331344.

[51] Walte, A.; Rüben, K.; Birner-Gruenberger, R., et al., Mechanism of dual specificity kinase activity of DYRK1A. FEBS Journal, 2013, n/a-n/a.

[52] Ryu, Y.S.; Park, S.Y.; Jung, M.S., et al., Dyrk1Amediated phosphorylation of Presenilin 1: a functional link between Down syndrome and Alzheimer's disease. $J$ Neurochem, 2010, 115, (3), 574-584.

[53] Kimura, R.; Kamino, K.; Yamamoto, M., et al., The DYRK1A gene, encoded in chromosome 21 Down syndrome critical region, bridges between beta-amyloid production and tau phosphorylation in Alzheimer disease. Hum Mol Genet, 2007, 16, (1), 15-23.

[54] Haas, C., Strategies, development, and pitfalls of therapeutic options for Alzheimer's disease. J Alzheimers Dis, 2012, 28, (2), 241-281.

[55] Castellani, R.J.; Nunomura, A.; Lee, H.G.; Perry, G.; Smith, M.A., Phosphorylated tau: toxic, protective, or none of the above. J Alzheimers Dis, 2008, 14, (4), 377-383.

[56] Walker, L.C.; Diamond, M.I.; Duff, K.E.; Hyman, B.T., Mechanisms of protein seeding in neurodegenerative diseases. JAMA Neurol, 2013, 70, (3), 304-310.

[57] Barnham, K.J.; Masters, C.L.; Bush, A.I., Neurodegenerative diseases and oxidative stress. Nat Rev Drug Discov, 2004, 3, (3), 205-214.

[58] Nunomura, A.; Perry, G.; Aliev, G., et al., Oxidative damage is the earliest event in Alzheimer disease. J Neuropathol Exp Neurol, 2001, 60, (8), 759-767.

[59] Zarkovic, K., 4-hydroxynonenal and neurodegenerative diseases. Mol Aspects Med, 2003, 24, (45), 293-303.

[60] Butterfield, D.A.; Castegna, A.; Lauderback, C.M.; Drake, J., Evidence that amyloid beta-peptide-induced lipid peroxidation and its sequelae in Alzheimer's disease brain contribute to neuronal death. Neurobiol Aging, 2002, 23, (5), 655-664.

[61] Gandhi, S.; Abramov, A.Y., Mechanism of oxidative stress in neurodegeneration. Oxid Med Cell Longev, 2012, 2012, 428010.

[62] Selley, M.L.; Close, D.R.; Stern, S.E., The effect of increased concentrations of homocysteine on the concentration of (E)-4-hydroxy-2-nonenal in the plasma and cerebrospinal fluid of patients with Alzheimer's disease. Neurobiol Aging, 2002, 23, (3), 383-388. 
[63] Gabbita, S.P.; Lovell, M.A.; Markesbery, W.R., Increased nuclear DNA oxidation in the brain in Alzheimer's disease. J Neurochem, 1998, 71, (5), 2034-2040.

[64] Lovell, M.A.; Gabbita, S.P.; Markesbery, W.R., Increased DNA oxidation and decreased levels of repair products in Alzheimer's disease ventricular CSF. $J$ Neurochem, 1999, 72, (2), 771-776.

[65] Shan, X.; Tashiro, H.; Lin, C.L., The identification and characterization of oxidized RNAs in Alzheimer's disease. J Neurosci, 2003, 23, (12), 4913-4921.

[66] Singh, M.; Dang, T.N.; Arseneault, M.; Ramassamy, C., Role of by-products of lipid oxidation in Alzheimer's disease brain: a focus on acrolein. J Alzheimers Dis, 2010, 21, (3), 741-756.

[67] Iulita, M.F.; Cuello, A.C., Nerve growth factor metabolic dysfunction in Alzheimer's disease and Down syndrome. Trends Pharmacol Sci, 2014, 35, (7), 338-348.

[68] Perry, E.K.; Johnson, M.; Ekonomou, A., et al., Neurogenic abnormalities in Alzheimer's disease differ between stages of neurogenesis and are partly related to cholinergic pathology. Neurobiol Dis, 2012, 47, (2), 155162.

[69] Pasinetti, G.M.; Ho, L.; Dooley, C.; Abbi, B.; Lange, G., Select non-coding RNA in blood components provide novel clinically accessible biological surrogates for improved identification of traumatic brain injury in OEF/OIF Veterans. Am J Neurodegener Dis, 2012, 1, (1), 88-98.

[70] Roberson, E.D.; Mucke, L., 100 years and counting: prospects for defeating Alzheimer's disease. Science, 2006, 314, (5800), 781-784.

[71] U.S. National Institutes of Health http://www.clinicaltrials.gov/ (June, 2015),

[72] Williams, R.J.; Spencer, J.P., Flavonoids, cognition, and dementia: actions, mechanisms, and potential therapeutic utility for Alzheimer disease. Free Radic Biol Med, 2012, 52, (1), 35-45.

[73] Ramassamy, C., Emerging role of polyphenolic compounds in the treatment of neurodegenerative diseases: a review of their intracellular targets. Eur J Pharmacol, 2006, 545, (1), 51-64.

[74] Yang, C.S.; Pan, E., The effects of green tea polyphenols on drug metabolism. Expert Opin Drug Metab Toxicol, 2012, 8, (6), 677-689.

[75] Aron, P.M.; Kennedy, J.A., Flavan-3-ols: nature, occurrence and biological activity. Mol Nutr Food Res, 2008, 52, (1), 79-104.

[76] Miller, R.J.; Jackson, K.G.; Dadd, T., et al., A preliminary investigation of the impact of catechol-Omethyltransferase genotype on the absorption and metabolism of green tea catechins. Eur J Nutr, 2012, 51, (1), 47-55.

[77] Suzuki, Y.; Miyoshi, N.; Isemura, M., Healthpromoting effects of green tea. Proc Jpn Acad Ser B Phys Biol Sci, 2012, 88, (3), 88-101.

[78] Kuriyama, S.; Hozawa, A.; Ohmori, K., et al., Green tea consumption and cognitive function: a cross- sectional study from the Tsurugaya Project 1. Am J Clin Nutr, 2006, 83, (2), 355-361.

[79] Meng, X.; Sang, S.; Zhu, N., et al., Identification and characterization of methylated and ring-fission metabolites of tea catechins formed in humans, mice, and rats. Chem Res Toxicol, 2002, 15, (8), 1042-1050.

[80] Zuo, Z.; Zhang, L.; Zhou, L. In Tea in Health and Disease Prevention; Academic Press, 2013, pp 399-412.

[81] Sang, S.; Lambert, J.D.; Ho, C.T.; Yang, C.S., The chemistry and biotransformation of tea constituents. Pharmacol Res, 2011, 64, (2), 87-99.

[82] Lu, H.; Meng, X.; Li, C., et al., Glucuronides of tea catechins: enzymology of biosynthesis and biological activities. Drug Metab Dispos, 2003, 31, (4), 452-461.

[83] Del Rio, D.; Calani, L.; Cordero, C., et al., Bioavailability and catabolism of green tea flavan-3-ols in humans. Nutrition, 2010, 26, (11-12), 1110-1116.

[84] Lambert, J.D.; Sang, S.; Yang, C.S., Biotransformation of green tea polyphenols and the biological activities of those metabolites. Mol Pharm, 2007, 4, (6), 819-825.

[85] Yang, C.S.; Chen, L.; Lee, M.J., et al., Blood and urine levels of tea catechins after ingestion of different amounts of green tea by human volunteers. Cancer Epidemiol Biomarkers Prev, 1998, 7, (4), 351-354.

[86] Chow, H.H.; Cai, Y.; Alberts, D.S., et al., Phase I pharmacokinetic study of tea polyphenols following singledose administration of epigallocatechin gallate and polyphenon E. Cancer Epidemiol Biomarkers Prev, 2001, 10, (1), 53-58.

[87] Suganuma, M.; Okabe, S.; Oniyama, M., et al., Wide distribution of $[3 \mathrm{H}](-)$-epigallocatechin gallate, a cancer preventive tea polyphenol, in mouse tissue. Carcinogenesis, 1998, 19, (10), 1771-1776.

[88] Chu, K.O.; Wang, C.C.; Chu, C.Y., et al., Determination of catechins and catechin gallates in tissues by liquid chromatography with coulometric array detection and selective solid phase extraction. J Chromatogr B Analyt Technol Biomed Life Sci, 2004, 810, (2), 187-195.

[89] Yano, S.; Fujimura, Y.; Umeda, D., et al., Relationship between the biological activities of methylated derivatives of (-)-epigallocatechin-3-O-gallate (EGCG) and their cell surface binding activities. J Agric Food Chem, 2007, 55, (17), 7144-7148.

[90] Lotito, S.B.; Zhang, W.J.; Yang, C.S.; Crozier, A.; Frei, B., Metabolic conversion of dietary flavonoids alters their anti-inflammatory and antioxidant properties. Free Radic Biol Med, 2011, 51, (2), 454-463.

[91] Mandel, S.; Youdim, M.B., Catechin polyphenols: neurodegeneration and neuroprotection in neurodegenerative diseases. Free Radic Biol Med, 2004, 37, (3), 304-317.

[92] Na, H.-K.; Surh, Y.-J., Modulation of Nrf2mediated antioxidant and detoxifying enzyme induction by the green tea polyphenol EGCG. Food and Chemical Toxicology, 2008, 46, (4), 1271-1278. 
[93] LaFerla, F.M.; Green, K.N., Animal models of Alzheimer disease. Cold Spring Harb Perspect Med, 2012, 2, (11).

[94] Levites, Y.; Amit, T.; Mandel, S.; Youdim, M.B., Neuroprotection and neurorescue against Abeta toxicity and PKC-dependent release of nonamyloidogenic soluble precursor protein by green tea polyphenol (-)epigallocatechin-3-gallate. FASEB J, 2003, 17, (8), 952-954.

[95] Lin, C.L.; Chen, T.F.; Chiu, M.J.; Way, T.D.; Lin, J.K., Epigallocatechin gallate (EGCG) suppresses betaamyloid-induced neurotoxicity through inhibiting cAbl/FE65 nuclear translocation and GSK3 beta activation. Neurobiol Aging, 2009, 30, (1), 81-92.

[96] Choi, S.M.; Kim, B.C.; Cho, Y.H., et al., Effects of Flavonoid Compounds on beta-amyloid-peptide-induced Neuronal Death in Cultured Mouse Cortical Neurons. Chonnam Med J, 2014, 50, (2), 45-51.

[97] He, Y.; Cui, J.; Lee, J.C., et al., Prolonged exposure of cortical neurons to oligomeric amyloid-beta impairs NMDA receptor function via NADPH oxidase-mediated ROS production: protective effect of green tea (-)epigallocatechin-3-gallate. ASN Neuro, 2011, 3, (1), e00050.

[98] Zhang, X.; Wu, M.; Lu, F., et al., Involvement of alpha7 nAChR signaling cascade in epigallocatechin gallate suppression of beta-amyloid-induced apoptotic cortical neuronal insults. Mol Neurobiol, 2014, 49, (1), 66-77.

[99] Haque, A.M.; Hashimoto, M.; Katakura, M.; Hara, Y.; Shido, O., Green tea catechins prevent cognitive deficits caused by Abeta1-40 in rats. J Nutr Biochem, 2008, 19, (9), 619-626.

[100] Lee, J.W.; Lee, Y.K.; Ban, J.O., et al., Green tea ()-epigallocatechin-3-gallate inhibits beta-amyloid-induced cognitive dysfunction through modification of secretase activity via inhibition of ERK and NF-kappaB pathways in mice. J Nutr, 2009, 139, (10), 1987-1993.

[101] Lee, Y.K.; Yuk, D.Y.; Lee, J.W., et al., (-)Epigallocatechin-3-gallate prevents lipopolysaccharideinduced elevation of beta-amyloid generation and memory deficiency. Brain Res, 2009, 1250, 164-174.

[102] Walker, J.M.; Klakotskaia, D.; Ajit, D., et al., Beneficial Effects of Dietary EGCG and Voluntary Exercise on Behavior in an Alzheimer's Disease Mouse Model. $J$ Alzheimers Dis, 2014.

[103] Reznichenko, L.; Amit, T.; Youdim, M.B.; Mandel, S., Green tea polyphenol (-)-epigallocatechin-3-gallate induces neurorescue of long-term serum-deprived PC12 cells and promotes neurite outgrowth. J Neurochem, 2005, 93, (5), 1157-1167.

[104] Arendash, G.W.; Lewis, J.; Leighty, R.E., et al., Multi-metric behavioral comparison of APPsw and P301L models for Alzheimer's disease: linkage of poorer cognitive performance to tau pathology in forebrain. Brain Res, 2004, 1012, (1-2), 29-41.

[105] Rezai-Zadeh, K.; Arendash, G.W.; Hou, H., et al., Green tea epigallocatechin-3-gallate (EGCG) reduces betaamyloid mediated cognitive impairment and modulates tau pathology in Alzheimer transgenic mice. Brain Res, 2008, 1214, 177-187.

[106] Li, Q.; Zhao, H.F.; Zhang, Z.F., et al., Long-term administration of green tea catechins prevents age-related spatial learning and memory decline in C57BL/6 J mice by regulating hippocampal cyclic amp-response element binding protein signaling cascade. Neuroscience, 2009, 159, (4), 1208-1215.

[107] Li, Q.; Zhao, H.F.; Zhang, Z.F., et al., Long-term green tea catechin administration prevents spatial learning and memory impairment in senescence-accelerated mouse prone-8 mice by decreasing Abeta1-42 oligomers and upregulating synaptic plasticity-related proteins in the hippocampus. Neuroscience, 2009, 163, (3), 741-749.

[108] Jia, N.; Han, K.; Kong, J.J., et al., (-)Epigallocatechin-3-gallate alleviates spatial memory impairment in APP/PS1 mice by restoring IRS-1 signaling defects in the hippocampus. Mol Cell Biochem, 2013.

[109] Liu, M.; Chen, F.; Sha, L., et al., (-)Epigallocatechin-3-Gallate Ameliorates Learning and Memory Deficits by Adjusting the Balance of TrkA/p75 Signaling in APP/PS1 Transgenic Mice. Mol Neurobiol, 2013.

[110] Wang, Y.; Li, M.; Xu, X., et al., Green tea epigallocatechin-3-gallate (EGCG) promotes neural progenitor cell proliferation and sonic hedgehog pathway activation during adult hippocampal neurogenesis. Mol Nutr Food Res, 2012, 56, (8), 1292-1303.

[111] Biasibetti, R.; Tramontina, A.C.; Costa, A.P., et al., Green tea (-)epigallocatechin-3-gallate reverses oxidative stress and reduces acetylcholinesterase activity in a streptozotocin-induced model of dementia. Behav Brain Res, 2013, 236, (1), 186-193.

[112] Lee, Y.J.; Choi, D.Y.; Yun, Y.P., et al., Epigallocatechin-3-gallate prevents systemic inflammationinduced memory deficiency and amyloidogenesis via its anti-neuroinflammatory properties. J Nutr Biochem, 2013, 24, (1), 298-310.

[113] Villarreal, A.; Aviles Reyes, R.X.; Angelo, M.F.; Reines, A.G.; Ramos, A.J., S100B alters neuronal survival and dendrite extension via RAGE-mediated NF-kappaB signaling. J Neurochem, 2011, 117, (2), 321-332.

[114] Rezai-Zadeh, K.; Shytle, D.; Sun, N., et al., Green tea epigallocatechin-3-gallate (EGCG) modulates amyloid precursor protein cleavage and reduces cerebral amyloidosis in Alzheimer transgenic mice. J Neurosci, 2005, 25, (38), 8807-8814.

[115] Reznichenko, L.; Amit, T.; Zheng, H., et al., Reduction of iron-regulated amyloid precursor protein and beta-amyloid peptide by (-)-epigallocatechin-3-gallate in cell cultures: implications for iron chelation in Alzheimer's disease. J Neurochem, 2006, 97, (2), 527-536.

[116] Obregon, D.F.; Rezai-Zadeh, K.; Bai, Y., et al., ADAM10 activation is required for green tea (-)epigallocatechin-3-gallate-induced alpha-secretase cleavage 
of amyloid precursor protein. J Biol Chem, 2006, 281, (24), 16419-16427.

[117] Fernandez, J.W.; Rezai-Zadeh, K.; Obregon, D.; Tan, J., EGCG functions through estrogen receptor-mediated activation of ADAM10 in the promotion of nonamyloidogenic processing of APP. FEBS Lett, 2010, 584, (19), 4259-4267.

[118] Shimmyo, Y.; Kihara, T.; Akaike, A.; Niidome, T.; Sugimoto, H., Epigallocatechin-3-gallate and curcumin suppress amyloid beta-induced beta-site APP cleaving enzyme-1 upregulation. Neuroreport, 2008, 19, (13), 13291333.

[119] Rushworth, J.V.; Griffiths, H.H.; Watt, N.T.; Hooper, N.M., Prion protein-mediated toxicity of amyloidbeta oligomers requires lipid rafts and the transmembrane LRP1. J Biol Chem, 2013.

[120] Adayev, T.; Chen-Hwang, M.C.; Murakami, N.; Wegiel, J.; Hwang, Y.W., Kinetic properties of a MNB/DYRK1A mutant suitable for the elucidation of biochemical pathways. Biochemistry, 2006, 45, (39), 1201112019.

[121] Guedj, F.; Sebrie, C.; Rivals, I., et al., Green tea polyphenols rescue of brain defects induced by overexpression of DYRK1A. PLoS One, 2009, 4, (2), e4606.

[122] Romeo, L.; Intrieri, M.; D'Agata, V., et al., The major green tea polyphenol, (-)-epigallocatechin-3-gallate, induces heme oxygenase in rat neurons and acts as an effective neuroprotective agent against oxidative stress. $J \mathrm{Am}$ Coll Nutr, 2009, 28 Suppl, 492S-499S.

[123] Scapagnini, G.; Vasto, S.; Abraham, N.G., et al., Modulation of Nrf2/ARE pathway by food polyphenols: a nutritional neuroprotective strategy for cognitive and neurodegenerative disorders. Mol Neurobiol, 2011, 44, (2), 192-201.

[124] Na, H.K.; Kim, E.H.; Jung, J.H., et al., (-)Epigallocatechin gallate induces Nrf2-mediated antioxidant enzyme expression via activation of PI3K and ERK in human mammary epithelial cells. Arch Biochem Biophys, 2008, 476, (2), 171-177.

[125] Na, H.K.; Surh, Y.J., Modulation of Nrf2-mediated antioxidant and detoxifying enzyme induction by the green tea polyphenol EGCG. Food Chem Toxicol, 2008, 46, (4), 1271-1278.

[126] Cheng, X.; Ku, C.H.; Siow, R.C., Regulation of the Nrf2 antioxidant pathway by microRNAs: New players in micromanaging redox homeostasis. Free Radic Biol Med, 2013, 64, 4-11.

[127] Khan, S.I.; Aumsuwan, P.; Khan, I.A.; Walker, L.A.; Dasmahapatra, A.K., Epigenetic events associated with breast cancer and their prevention by dietary components targeting the epigenome. Chem Res Toxicol, 2012, 25, (1), 61-73.

[128] Kim, Y.S.; Farrar, W.; Colburn, N.H.; Milner, J.A., Cancer stem cells: potential target for bioactive food components. J Nutr Biochem, 2012, 23, (7), 691-698.
[129] Srividhya, R.; Jyothilakshmi, V.; Arulmathi, K.; Senthilkumaran, V.; Kalaiselvi, P., Attenuation of senescence-induced oxidative exacerbations in aged rat brain by (-)-epigallocatechin-3-gallate. Int J Dev Neurosci, 2008, 26, (2), 217-223.

[130] Unno, K.; Takabayashi, F.; Kishido, T.; Oku, N., Suppressive effect of green tea catechins on morphologic and functional regression of the brain in aged mice with accelerated senescence (SAMP10). Exp Gerontol, 2004, 39, (7), 1027-1034.

[131] Unno, K.; Takabayashi, F.; Yoshida, H., et al., Daily consumption of green tea catechin delays memory regression in aged mice. Biogerontology, 2007, 8, (2), 89-95. [132] Gundimeda, U.; McNeill, T.H.; Fan, T.K., et al., Green tea catechins potentiate the neuritogenic action of brain-derived neurotrophic factor: role of 67-kDa laminin receptor and hydrogen peroxide. Biochem Biophys Res Commun, 2014.

[133] Mahler, A.; Steiniger, J.; Bock, M., et al., Metabolic response to epigallocatechin-3-gallate in relapsing-remitting multiple sclerosis: a randomized clinical trial. Am J Clin Nutr, 2015, 101, (3), 487-495.

[134] Kristen, A.V.; Lehrke, S.; Buss, S., et al., Green tea halts progression of cardiac transthyretin amyloidosis: an observational report. Clin Res Cardiol, 2012, 101, (10), 805813.

[135] Park, S.K.; Jung, I.C.; Lee, W.K., et al., A combination of green tea extract and l-theanine improves memory and attention in subjects with mild cognitive impairment: a double-blind placebo-controlled study. J Med Food, 2011, 14, (4), 334-343.

[136] Chow, H.H.; Cai, Y.; Hakim, I.A., et al., Pharmacokinetics and safety of green tea polyphenols after multiple-dose administration of epigallocatechin gallate and polyphenon E in healthy individuals. Clin Cancer Res, 2003, 9, (9), 3312-3319. 